\title{
The Political Side of Bilingual Education: the Undesirable Becomes Useful
}

\author{
(C) Jorge R. Schmidt-Nieto \\ Department of Social Sciences \\ University of Puerto Rico, Mayagüez Campus \\ E-mail - yoryi@caribe.net
}

\section{Introduction}

This paper approaches the study of bilingual education from a political science perspective, arguing that politics play a vital role in the processes leading to bilingual education programs. We need to understand how they do so as well as how to handle the effects on the policy outcomes, which can be approached from two perspectives. One is based on the concept of the social dilemma, by which groups acting rationally in their best self-interest may promote actions that are irrational for society at large. Those actors that can translate their preferences into public policies impose them upon the larger society, even if they involve high costs for other sectors or for the whole society. The official language policy of Spain under Franco, for instance, was based on the preferences of Madrid-based societal sectors that supported Franco's regime and who benefited from centralization and homogeneity at all levels. The policy failed to account for the regional strength of language groups such as Catalans and Basques, who managed to maintain their languages alive and reacted strongly against Spanish when given an opportunity, thus effectively reversing the centralizing policy. From this perspective, politics represent impediments to the establishment of effective educational language policies, and the solution lies in removing them from educational systems. A second approach is that politics are an intrinsic and inevitable part of the development of language educational policies that need to be understood and used to develop workable solutions to the challenges created by language groups in contact. From this perspective, Spain's problem was not the involvement of politics in the decision-making process, but the lack of democracy with which those politics were determined. The social dilemma is an inevitable element in educational language policies, and its solution rests on the formulation of language entrepreneurs' incentives that promote optimal social outcomes. Democratic educational institutions can provide such incentives. 
The first part of the paper explores how language contact affects power relations among language groups. It argues that the contact between these groups generates different accesses to political and economic opportunities, the management of which is essentially a political process. Language planning, the conscious effort by governments to manage language use in their societies, must begin with the acceptance that the relative importance of a language in government and economic processes may increase some groups' chances of social mobility while reducing those of other groups. This happens in five general arenas where language and politics collide: national identity, state bureaucratic efficiency, income distribution, political participation, and political culture. In the end, the political dimension of bilingual education, if properly understood, can be used to develop educational institutions capable of managing the power relations involved and to create practices that promote democratic and realistic solutions to bilingualism's many challenges. On the other hand, political scientists have underestimated consistently the role of language in politics, treating it as an independent variable that serves to explain other "larger" issues, such as nationalism and ethnicity [1]. In this regard, this project proposes the study of language as a dependent variable in political processes that needs to be studied and understood on its own merits.

The second part of the paper states that one of the most effective ways to affect the relative position of language groups is through their language's presence in educational systems. The determination of language policies promotes the emergence of language entrepreneurs, individuals who invest time, efforts and resources with the intention of receiving returns based on an increased presence of the language they defend [2]. Hence, political processes affect policy makers' decisions about educational language policies in similar ways than other state policies, such as macroeconomic policy, labor policies, or incomes policies. Departing from a political perspective, the section explores some ways in which educational systems may assimilate the political pressures of language groups. Specifically, the project proposes the inclusion of participation and decentralization within educational structures as a democratic approach towards channeling the language entrepreneurs' demands.

Next, the theoretical considerations are illustrated by the development of educational language policies in Puerto Rico during the first half of the twentieth century. Changes in decentralization and participation in Puerto Rico's Education Department opened and closed spaces of inclusion for the various groups affected by language policies related to the educational use of English. 


\section{Language and Politics}

The last two decades of the twentieth century witnessed a resurgence of ethnic and nationalist struggles around the globe, which provided bases for scholarly debates, in which language was recognized as one crucial aspect of ethnic identity and differentiation (Connor, 1994; Esman, 1994; Gellner, 1983; Kohn, 1982; Laitin, 1992, 1998; Smith, 1992). Contact among language groups produce power dynamics that have created complex challenges for government administrators. The following is a discussion of five main areas in which language and politics interact: formation of national identity, state bureaucratic efficiency, income distribution, political participation, and political culture.

\section{Formation of national identity}

Elements defining a nation are varied and interpretations of the process of nationality formation are numerous (Anderson, 1991; Connor, 1972; Smith, 1992; Kohn, 1982; Deutsch, 1966). Gellner (1983) refers to the process of nation formation as the development of a standardized, homogeneous, and centrally sustained high culture on a population. This dominant high culture manages to equate its defining elements with those of the state. Since most states are not homogeneous, the defining elements of other groups become subordinated to, and remain in tension with, those of the dominant group [3].

One of the most common elements that define a nation is language. When language is a determining component of a dominant group's identity, there is a tendency for that language to become associated with the state at the expense of other languages that correspond with competing language groups (Solé, 1995). For instance, the unification of the Spanish state in the fifteenth and sixteenth centuries not only established Castile's political and economic dominance, but also elevated its defining symbols to those of Spain, particularly the language (Laitin, Solé, and Kalyvas, 1994; Valleverdú, 1984). But Spain's unification under Castile remained uneasy with several conflicts revolving around the status of other regions and ethnic groups, especially Catalonia and the Basque Countries.

The dominant position of a language also affects self-perceptions and perceptions of others. The seminal study on language attitudes by Lambert, Hodgson, Gardner and Fillenbaum (in Hammers and Hummel, 1994) revealed that the use of English in Quebec was related to more favorable attitudinal values than the use of French. Subjects in the study were asked to evaluate voices of different 
speakers on scales based on status and solidarity. The voices were from the same individuals, equally proficient in English and French. English speakers were rated higher on positive values, especially by Francophone subjects. While the scope of the project was limited to a few individuals in Quebec and it could hardly lead to universal conclusions, it illustrated the tremendous effect of language domination in groups' self-perceptions [4].

\section{State bureaucratic efficiency}

State bureaucratic efficiency refers to the capacity of the state to perform administrative duties at the maximum level of utility. The existence of diverse language groups reduces a state's bureaucratic efficiency by increasing the costs of official communication at central and regional levels. Official documents may have to be translated, state funded public education may have to include several language courses, state offices may be forced to hire polyglot personnel, and translators may be needed for operations of the legal system. States may choose to operate in one language to reduce costs, but it would likely be at the expense of disrupting communication between the central government and regional political units, or among political units. Difficulty to communicate between the center and outlying areas limits the state's capacity to include some sectors of the population and provides real obstacles for the integration of those sectors into national life. This may affect social mobilization, the process by which isolated sectors of the population are drawn into fuller participation in public life through the opening of centers of political control, economic power, and innovation in outlying areas (Deutsch, 1961).

The tension between language diversity and language rationalization provides tremendous challenges for policy-makers in multilingual societies. Laponce (1987) argues that, as states become more urbanized and industrialized, and ethnic conflicts resulting from language contact increase, politicians have strong incentives to reduce language diversity through official policies of rationalization [5]. Such policies threaten the survival of small language groups, which are likely to react by placing demands on governments to establish policies that can improve their chances of survival. Although rationalization policies may prove to be too strong against the survival of some language communities, such as Asturian in Spain, Cornish in England, Egyptian in Egypt, and many Native American languages in the Americas, others may be more resilient, like French in Canada, Náhuatl in México, and most of the state languages in India. 


\section{Income distribution}

Language issues affect income distribution by influencing differences in employment opportunities among language groups. Preference of a language by private enterprises limits employment offers to individuals from sectors or regions with proficiency in that language. Population sectors that lack proficiency in that preferred language become marginalized, while those possessing the language skills reap larger shares of the employment pie. Hence, language diversity may transform or reinforce class cleavages. In Quebec, for instance, preference for English in the workplace created earning differentials between Francophones and Anglophones, at least until the early 1970's (Grin, 1996; Hamers and Hummel, 1994; Endleman, 1995). Successive legislation in Quebec's Parliament since 1969 imposed the use of French in the workplace and faced a strong reaction from civil rights groups, but had a noticeable impact in reducing income inequality gaps between Anglophones and Francophones [6].

Language diversity can also contribute to social stratification through the use of various languages at different levels of production. For instance, one language may be used at shop levels and another at managerial positions. This is the situation of many Spanish-speaking factory workers in large U.S. cities, whose supervisors speak only English and establish communication through intermediate level supervisors that serve as interpreters. A similar case can be made for agricultural industries in states such as California, where Spanishspeaking immigrants work the fields while English-speaking, AngloSaxon individuals occupy managerial positions (Solé, 1995). Language can provide a foundation for the permanence of class differentiations between language groups and, in the U.S. case, between ethnic groups as well (Bloom and Grenier, in Crawford, 1992: 445-451).

\section{Political participation}

Language diversity affects political participation by excluding from national political life individuals and population sectors that cannot communicate in the language or languages of the state. Parliamentary debates are held in one language or possibly two, but a plurality of languages would make communication hopeless in legislative discussions. Local or regional parliaments, assemblies or governorships may allow the use of other languages and permit some levels of participation by individuals who do not speak the state language. This practice, however, hinders national leaders' capacity to communicate with regional governments and population sectors that do not speak the central language. Interpreters can and are often 
used, but the increase in costs and efforts to communicate produce biases against full inclusion of marginalized language groups in political decisions.

Language diversity can be used to exclude popular sectors from access to political power. Rahman (1996) shows how Punjabi elites in Pakistan have used Urdu and English to exclude large numbers of people from government posts. Urdu, spoken by approximately 8 percent of the population, has preference over Punjabi, the mother tongue of over 48 percent of the Pakistani people. French and Belgian colonial policies in Africa and Asia provided access to French training only to a handful of privileged people who could serve as trained native auxiliaries (Babault and Caitucoli, 1997: 160). The rest of the population remained intentionally excluded from access to political and economic power facilitated by French language proficiency. In independent Senegal, French, spoken by a small elite, was chosen as the official language of government in spite of Wolof being spoken by over $90 \%$ of the population (Grosjean, 1982). Another instance is Haiti, where a majority of the population speaks Creole while French dominates the official life and educational system.

\section{Political culture}

Laitin (1977: 4, 139) observes that if there is any truth to the linguistic relativists' claim that language patterns both form and maintain cultural norms, then language policies aimed at changing language patterns may ultimately transform political culture. It is possible that "to change the language of a political community is to change its political culture" (Laitin, 1977: 2). He examines, in the Somali case, the spread of European (colonial) languages and its implications for African political culture of. Some preliminary conclusions include the more egalitarian and less confrontational nature of values associated with Somali than with English, and a stronger tendency to confound religious and secular values in the use of Somali (1977: 223).

Diglossic relations among languages may also affect political culture. DasGupta (1970) evaluates the importance of language roles in traditional sectors of large societies, like India, where various social activities are carried out in different languages. Administrative affairs may be carried out in the colonial language, religious ceremonies may be held in an ancient sacred language, while at home yet another language may be spoken. Values associated with different activities are coded in language. Hence, a person using various languages in different roles may project different worldviews according to the language used. This difference in cosmology occurs often in modernization processes, where administrative languages become 
associated with progressive views while local languages are identified with traditional ways of life and backwardness (Fishman, 1968). This tension surfaces in newly independent states when issues of economic development and political equality are brought to the forefront of national debate. For many postcolonial regimes, European languages have remained associated with modernity and have preserved privileged places in official settings [7]. The belief that associates European languages with progress and non-European languages with stagnation is one that developing countries are only starting to dismantle but that still carries tremendous weight in decisions about language instruction.

\section{Educational Institutions and Language Entrepeneurs}

The political implications of language are most evident in the link between education and state formation. Benedict Anderson (1991) links the development of nation-states in Europe to the emergence of what he terms "print-capitalism," which is the invention of the printing press coupled with the rise of a capitalist mode of production. The success of print capitalism depended on large numbers of literate people, mostly within the bourgeoisie. The establishment of mass educational systems and the reduction of illiteracy helped extend new economic relations to larger societal sectors. Print capitalism also provided incentives for the creation of grammars and dictionaries, which were used in educational systems and helped disseminate standard languages. The choice of languages in education became political decisions that reflected states' power relations among competing language groups. Modern public education systems emerged as agencies that could reinforce or transform existing social cleavages by either maintaining the use of a language or creating new communication habits.

In order to understand the role of educational systems as scenarios of power struggles related to language outcomes, it is necessary to discuss the significance of power distribution for deciding policy in educational systems, as well as to identify the various actors involved in determining educational language policies (language entrepreneurs), their general preferences, and the impact of institutions in those preferences.

\section{Power distribution in educational systems}

The distribution of authority within an educational system is essentially an issue of power allocation among actors. Since the various actors have different and sometimes conflicting preferences, the relative power allocation of educational systems affects which preferences 
dominate and, consequently, the types of policies established. Hence, one way to explain and predict educational language policies is through the observation of changes in power distribution in school systems. This argument does not deny that pedagogical considerations are intrinsic to policy decisions, but it stresses that political concerns are at least equally relevant and have strong and independent effects on policy outcomes.

Patterns of power distribution in schools systems can be observed in two ways. One is where policies are developed; the other is who creates them. The first refers to the various levels of decision-making: central educational ministry, regional or state body, school district, or individual school. The closer decisions are made to the central authority, the more centralized becomes the system. The aspect of who makes policies refers to the relative participation of administrators, teachers, and parents. Each group brings a particular and unique perspective to the educational process, which is reflected in their preferences over school policies. Those perspectives meet on institutional arenas that provide incentives and constraints that modify the actors' preferences.

A large part of the literature on the debate over school reform assumes increases in decentralization to be accompanied by growth in participation from non-bureaucratic actors (Beadie, 1996; Hannaway and Carnoy, 1993; Clune, 1993; Lauglo, 1995), with important exceptions (Conley, 1991; Keith, 1996). This assumption overlooks the difference between the participation and decisionmaking levels. Decentralized systems may be participatory in the sense of allowing lower hierarchical levels to take part in decisionmaking, but they may not be inclusive to groups outside the bureaucratic echelons. Vexliard (1970:44) points to the case of occupied Japan, where American authorities imposed decentralizing measures in the educational system, only to allow reactionary and anti-democratic local authorities to seize control of many school districts. In contrast, centralized systems may be inclusive; some groups demanding participation may prefer them over decentralized systems. National teachers' unions, for instance, have strong incentives to claim inclusion in decision-making at central levels, where their power in numbers is large, rather than attempting participation in decentralized, smaller units, where their strength may be reduced. Thus, decentralization and participation are two distinct features of educational systems with independent effects on policy outcomes. 


\section{Language entrepreneurs: administrators, teachers, and parents}

In order to understand the policy effects of power allocation patterns in educational systems, I will examine the language entrepreneurs involved in the decision-making process and their preferences regarding educational language use. Since preferences do not exist in vacuums, the project explores how those preferences are affected by the administrative levels at which language policies are determined, and by their relative capacity to participate in educational policymaking.

\section{Administrators}

School administrators make up the bureaucracy of educational systems and include school principals, district superintendents, and central office executives. They face pressures from above and below, regardless of the level at which they operate. School principals receive claims from teachers and superintendents; superintendents encounter demands from principals, school boards, and central offices; central offices confront challenges from teachers' unions, government officials and legislators (Boyan, 1988a; Greenfield, 1995). Administrators are pivotal ingredients in the negotiated social order that is the school system (Greenfield, 1995; Bacharach and Mundell, 1993; Corwin and Borman, 1988), and are ultimately responsible for the school system's performance. Since different levels of administration face demands from different groups, the institutional effects on administrators' preferences vary according to the level of administration.

One of the main interests of administrators is efficiency (Marshall, 1991). Public school systems are almost invariably under funded, an almost inevitable consequence of the attempt to educate whole populations. Thus, administrators must care for numerous needs with limited budgets, and short-term, inexpensive and productive programs tend to be favored over long-term, expensive, and inefficient programs.

Administrators also seek stability and avoidance of crises (Greenfield, 1995; Corwin and Borman, 1988). The value of policy changes tends to be weighted against their potential destabilizing effects. Hence, administrators may favor change and innovation, but only if they do not threat the precarious negotiated order of school operations. In an empirical study of several schools in the United States that experimented with shared decision-making, Weiss (1993) found that most of the drive for innovation came from school principals, rather than teachers. Weiss attributed this drive to the administrators' access to resources, their opportunity to communicate with wide sectors of 
the schools system (teachers and parents), and their authority to bring the proposals to the attention of the school community (1993:83). However, the study also found that most of the changes focused on increasing the community's involvement in the traditional roles assigned to teachers, but little to challenge the administrators' leadership. The implications of such changes may have impacted the teaching aspects of schools' operations, but not the stability of administrators as ultimate overseers of schools' performance. Another empirical study held by Bryant (1998), compared the attempts by two principals to establish school governance reforms at different times in an inner city school in the southeastern United States. While both implemented similar changes, they faced different structural constraints and incentives that allowed one to succeed and forced the other to fail. The failed attempt, according to Bryant, was doomed by the principal's incapacity to maintain a stable leadership role within the school community. When the reforms threatened the principal's leadership role, the principal's actions became conservative and stopped reform. In the successful case, in which the school principal was able to promote reforms without jeopardizing his leadership position, he became an agent for change. More empirical research is still needed on this area, but Weiss' and Bryant's findings provide strong support for the assumption that administrators may encourage change if it does not impair the system's stability.

Administrators' general inclinations on language policies are closely linked to their preferences for efficiency and stability. The use of various languages in education per se, need not run against administrators' preferences, but their potential detrimental effects on efficiency and stability tend to provide incentives for administrators to prefer the use of the fewer languages possible. The use of various languages reduces efficiency by increasing communication costs and by multiplying costs for texts and teaching materials. Those effects are more evident at central educational institutions than at local school institutions, since central organisms handle larger areas than their local counterparts. On the other hand, the use of various languages can deepen administrative instability by increasing the uncertainty of results in educational policy changes. Since school performance is ultimately viewed as the administrators' responsibility, the uncertainty produced by the increment in educational roles to otherwise relatively minor languages provide incentives for bureaucrats to view with skepticism the inclusion of new languages. As with efficiency, localized expansion of language educational use increases uncertainty at lower rates than at central levels. This is true because it is easier to collect information from smaller areas and produce policies with more limited scopes. 
In sum, administrators' preferences on language policies are influenced by the potential effects on efficiency and stability, and by the relative level of decision-making decentralization. Educational structures with centralized decision-making provide incentives for administrators against language diversity in education because they increase the potential negative effects on efficiency and stability.

\section{Parents}

Parents' participation in education may take many forms, such as assisting at home with their children's homework, joining parentteacher associations, or becoming representatives in school councils. Out of all the actors involved in the educational process, parents are likely to be the least knowledgeable about school operations. This lack of information accounts for a typical reluctance from parents to participate in school decision-making processes (Bauch and Goldring, 1998:21; Fine 1993:697). This reluctance may stem from their belief that they don't have enough knowledge about education and a sense of intimidation from education professionals (teachers and administrators). Socio-economic status plays a large role in this sense of intimidation, since more educated parents tend to perceive a shorter distance between them and educators than less educated parents (Kohn, 1998; Becker, Nakagawa, and Corwin, 1997). On the other hand, school administrators and teachers often seek parental involvement for crises interventions, in moments when schools' performances are low and parents receive part of the blame for not providing the necessary support at home. Thus, an adversarial relationship between parents and school professionals is not uncommon, based on the dominant model for parental involvement, which ascribes parents an unequal status and a role of supporters and learners of professional educators with little voice in real decisionmaking (Vincent, 1996:476). More participatory roles for parents are rare, with important exceptions, such as the trend-setting Chicago decentralized school system, placed in effect by legislation in 1989 (Fine, 1993:700; Bauch and Goldring, 1998:22; Vincent, 1996).

Another potential barrier against parental inclusion is the set of demands placed on individuals from other social institutions, such as work and family. For instance, schools may require monthly attendance to parent-teacher meetings at school, which may force some parents to take time off from inflexible jobs or lose wages. In other instances, such as those of single parents, becoming involved in their children's schoolwork at home may be unrealistic after working long days with long commutes (Fine, 1993:687). School reforms 
aimed at increasing parental roles may, then, face challenges that go beyond pedagogical considerations.

Participation from parents may also be hindered by collective action problems presented by the temporary nature of their status as parents of school children. Since children stay in school for a given number of years, the group of parents is constantly changing, so incentives to organize must be continually renewed and even renegotiated.

In terms of preferences, significant differences have been found based on socioeconomic status, educational levels, ethnicity, culture, and gender (Lewis, 1995; Dodd, 1996; Casanova, 1996; Vincent, 1996; Bryant, 1998; Kohn, 1998). There are, however, several basic interests that parents share.

The main interest of parents is their children's academic success. Thus, their participation typically begins as a reaction to unsatisfactory performance by their children. This initial individual involvement may turn into a challenge to the politics of public education if the problem is blamed on systemic reasons (Fine, 1993:699).

Parents also expect schools to prepare their children for the future, either by reproducing their socioeconomic status or by improving on it (social mobility). This interest may take two specific demands on language use. First, parents seek to reproduce their group identity through their children, so they favor the use of their mother tongue, either as language of instruction or as a language course. Second, parents' own experiences with job markets and social mobility opportunities and obstacles, lead them to expect their children to learn the language or languages that will open, or maintain open, the doors to job markets and political participation spaces. This is the case of immigrants who understand that their mother tongue has little practical use. In many instances, immigrants do not want their children to learn their language, believing that it hinders opportunities for social mobility. However, in an educational environment where community interests were included, the belief in the positive functional position of the dominant language would not preclude the use of minority languages. Thus, language preferences could include their mother tongue with attention to languages with potential for social mobility. The complexity of a school curriculum allows for the intense use of more than one language, so parents whose mother tongues have little use in business or government transactions are likely to support the use of more than one language in their children's education if it does not preclude the mastering of the dominant language. 


\section{Teachers}

One of the most striking findings on empirical research about teachers' participation patterns is a tendency towards non-involvement in policy issues due to the high costs of participation (Weiss, 1993; Beadie, 1996). Those costs include increased time demands, loss of autonomy within the classroom, risk of collegial disfavor, subversion of collective bargaining, and threats to career advancement (Duke, Showers and Imber, 1980:95-97). Benefits, on the other hand, are reduced to feelings of self-efficacy, increased sense of ownership, and exercise of workplace democracy (Duke, Showers and Imber, 1980:98-99). The single most important incentive for teachers' participation is the perception of influence over educational policy decision-making (Duke, Showers and Imber, 1980:104).

Influence on policy-making reduces the probability of being seen by peers as co-opted by the administration, provides a sense that the sacrifices involved with the increased time demands have concrete effects on their jobs and their students' education, and reduces the threats to career advancement by increasing the teachers' share of power within the school system. One reason for the failure of so many decentralization schemes is that they have moved the locus of decision-making away from the central office towards the district or school but have not provided influence for teachers (Beadie, 1996; Weiss, 1993). In fact, teachers have sometimes been the strongest opponents of decentralization plans [8]. Changes in educational structures that provide influence for teachers may provide incentives to become involved by reducing the costs of participation.

Teachers' preferences in terms of particular policies may vary, but there is one common element in all of them: job security (Beadie, 1996; Verdugo, Greenberg, Henderson, Uribe, and Schneider, 1997). This element stems from the teachers' role as salaried professionals. Regardless of policy preferences or pedagogical inclinations, teachers must remain in the job to influence policy. Hence, at any level of decision-making, teachers' primary preference will be the maintenance of their jobs. If job security is threatened, everything else is secondary. Teachers' unions are particularly important in this respect, since their own existence is often a product of teachers' insecure tenure.

Another common element among teachers is a sense of ownership within the classroom. Teachers' classroom behavior is difficult to supervise on a daily basis, so there is a tendency for teachers to develop a great deal of autonomy. Institutional changes that threaten to diminish that autonomy, either by increased supervision or by intervention of non-educators in instructional matters, antagonize the 
teachers' interests. Thus, while teachers generally favor some kind of influence in policy-making, they oppose it if it is accompanied by decreases in classroom autonomy (Beadie, 1996:84; Weiss, 1993).

While non-involvement may be a tendency for individual teachers, teacher union leaders have strong incentives towards participation. That participation may take many forms, from small, local unions to large, central organizations. Leaders of central unions are inclined to favor centralized educational structures because negotiations at central levels provide them with the strength in numbers and wide scale capacity to disrupt the school system's operations, something that would be more difficult with decentralized teachers unions. Teachers unions have opposed school decentralization schemes often on such grounds. In Puerto Rico, for instance, the centralized teachers unions Federación de Maestros and Asociación de Maestros opposed-unsuccessfully-Education Secretary Víctor Fajardo's creation of the decentralized Escuelas de la Comunidad in 1995, on the basis that they effectively reduced teachers' influence over policy making and hiring practices by attempting to fragment their power.

Teachers' preferences over language use depend on the language in current use, the potential costs of learning a new language (financial, time, and job security costs), and the costs of creating new teaching materials if they do not exist. Teachers' participation in low levels of decision-making increase the chances of having teachers for whom the benefits of using a minority language outweigh the costs because it is more likely that the minority language is their own. On the other hand, participation of teachers' organizations at centralized levels may tend to follow the state's rationalizing tendency because the costs of using languages other than the central language may outweigh the benefits of using smaller languages. Ultimately, then, levels of decision-making affect teachers' interests, where low levels reduce the costs of establishing language educational policies that reflect variations in communities' language use, while high levels increase incentives to support language rationalization policies that do not reflect linguistic diversity.

\section{Language entrepreneurs: political parties and politicians}

Language entrepreneurs working outside the realm of educational institutions may influence internal processes from external sources. Politicians may be important entrepreneurs in educational language policies, such as the political parties were in Puerto Rico during the first half of the twentieth century. They may value particular educational policies and may be very active in pursuing their goals. However, their interests are filtered through the decision-making 
structures of educational systems. Their involvement is qualitatively different from that of administrators, teachers or parents, in that their participation is indirect, however influential it may be. Their preferences vary substantially and need to be placed within specific historical and circumstantial contexts. Their preferences also vary according to their constituencies, which may be arranged according to ethnicity or nationality, socioeconomic class, ideology, and others.

\section{Effects of educational institutions on preferences}

At first blush, one would be surprised to find any attempts at nonbureaucratic participation and change in educational policies. It appears that if all actors acted rationally, change in school systems should be a rarity. However, most experts in school matters agree that educational systems should be inclusive and adaptive to new approaches and societal changes (Conley, 1991). Educational institutions can help solve this social dilemma, by altering teachers' and parents' utilities for participating in school politics through a reduction in administrators' risks in change and inclusion.

Decentralized and participatory educational institutions produce independent effects that, combined, establish those bases for the development of educational language policies that may reflect the true relationship among languages in a society. This is true for three reasons: First, because decentralized educational institutions affect administrators' incentives to accept language diversity in education; second, because decentralized structures reduce non-administrators' costs of involvement in policy-making, which increases their drive towards participation; and third, because participatory educational structures include non-bureaucratic preferences that may challenge the drive towards language rationalization of central administrators. The combination of decentralization and participation reduces administrators' pressures towards pursuing language rationalization policies and permits the influence of local societal sectors that are more sensitive to differences among communities' language use.

Decentralized structures reduce the negative effects on administrative efficiency produced by the use of various languages in education by decreasing the information gathering costs and limiting uncertainty of results. Administrators' preference towards language rationalization loses importance because efficiency and uncertainty are less threatening at local levels than at larger-scale, central operations.

Also, decentralized institutions reduce non-administrators' costs of involvement in decision-making by increasing their influence on policies that affect their communities more directly than those geared 
towards a wider set of school clients, in which their input would represent a smaller portion of the complete picture. Decentralized structures reduce the risk of participating without exercising real influence, which in turn increases teachers' incentives to become involved.

If decentralization promotes participation, the latter foments the inclusion of non-bureaucratic preferences that may challenge the drive towards language rationalization of central administrators. Hence, the involvement of groups whose rational calculations steer them away from language rationalization tend to produce educational policies that reflect and respect linguistic diversity. Conversely, structures that do not provide participation incentives for teachers and parents are likely to influence educational language policies dominated by one or few language groups.

When parents and teachers participate locally in order to respond to the needs of the community, and when administrators face demands from non-bureaucrats, educational language policies have a better chance of reflecting the true societal use of a language. It is true that conservatism is a dominant tendency for all three actors involved (administrators, teachers, and parents). However, inclusion and decentralization can alter the educational groups' conservative tendencies and allow for the establishment of policies that reflect communities' needs without forcing any groups to act against their own rational interests.

The following discussion provides empirical illustrations of the paper's theoretical arguments, and concentrates on three educational language policies in Puerto Rico between 1904 and 1949. It evaluates the effects of participation and decentralization on English language policies during the Falkner Policy (1904-1916), the Miller/Huyke Policy (1916-1934), and the Padín Policy (1934-1949).

\section{Language Education and Politics in Puerto Rico: 1904-1949}

Since the United States occupied the island in July of 1898, during the Spanish-American War, and the subsequent cession by Spain in December 1898, the development of a colonial policy by the United States became a salient consideration among Washington policy makers [9]. After a public and academic debate that produced a great deal of literature and congressional discussions, the prevailing approach in Washington towards Puerto Rico became that of "a systematic effort to fundamentally transform the country's administrative and legal systems and the political culture of the colonial subjects" (Cabán, 1998:1) into a set of values in concordance 
with the U.S. Anglo-Saxon cultural and political tradition. This process became known as the "Americanization" of Puerto Ricans, and the Puerto Rico Education Department emerged as the main tool of the strategy (Cabán, 1998; Negrón de Montilla, 1990; López Yustos, 1997; Morris, 1995; Solís, 1994; Algren de Gutiérrez, 1987; Cebollero, 1945; Brumbaugh, 1907; Clark, 1930).

The initial focus of the Americanization strategy was the introduction of English in schools, with the goal of replacing Spanish as the language of daily use for Puerto Ricans. Eventually this focus changed into one of maintaining Spanish while establishing English as a primary language. However, while the broad goals of the English policies were clear, the concrete interpretations of such policies were more ambiguous and allowed for differences of interpretation among various government administrations. The delegation of authority from the President of the United States to Puerto Rico's Governor and Education Commissioner opened spaces for variations in educational language policies. Hence, the explanation for the various changes in educational language policies lies within the structural changes of the Department of Education, which modified the language entrepreneurs' preferences and their capacities to impose them.

\section{The early politics of language instruction in Puerto Rico}

The use of the educational system in Puerto Rico as a tool for English language policies originated with John Eaton (1898-99), the first man in charge of education during the American military occupation. Together with Victor Clark (1899-1900), initially his assistant and later his replacement, Eaton established the tone for the next fifty years of language policies. Learning English was an essential aspect of the Americanizing goals, and the Education Department played a unique role in its implementation. The first educational institution created by the United States military regime was the Education Bureau, under the United States Department of the Interior.

The United States' Congress approved the Foraker Act in 1900 to create a civil government for the island, consisting of three republican branches of government. However, only the lower house of the legislature (House of Delegates) was popularly elected. The Governor of Puerto Rico and the Commissioner of Education were named by the United States' President. The Act created an Executive Council, which served as the legislative upper house and as the Governor's cabinet. All members of the council were named by the Governor, except some posts that were named by the United States' President (such as the Education Commissioner and the Attorney General). All judges of the Puerto Rican Supreme Court were named by the United 
States' President. Finally, the Foraker Act created the post of Resident Commissioner, a nonvoting delegate to the United States' House of Representatives.

One of the major pieces of legislation under the Foraker Act was the Official Languages Act of 1902. Approved at the initiative of the Executive Council, the law gave official status to both Spanish and English. The act was not intended to protect the rights of an Englishspeaking minority, but rather to establish the legal presence of English. It was also intended to allow the English-speaking administrators to conduct their businesses in English (Morris, 1995; Barreto, 1995). The Official Languages Act would be abolished in 1991 and reinstated in 1993.

The Foraker Act contained a section on the Education Commissioner's duties (section 25), which included direct participation over the educational laws and policies of the island. The Act, however, did not specify the Commissioner's administrative duties and the posts' limitations within the Education Department, which allowed the Commissioner to absorb a greater deal of power than was provided by the strict wording of the law (Negrón de Montilla, 1990:43) [10]. Under the rubric of the Foraker Act, the Puerto Rican Legislature approved the Act to Establish Public Schools in Puerto Rico on January 31, 1901, which created a centralized school system and placed virtually all powers in the hands of the Commissioner of Education (Solís, 1994:58-59). According to sections 4, 8, 14, 15, 18, and 20, the Commissioner could: order that schools enforce his directions, intervene in the placement of teachers, dismiss teachers, determine teachers' salaries, determine who would teach English, and institute disciplinary laws for teachers and students in schools (Solís, 1994:60; Negrón de Montilla, 1990:46-47).

The Department's centralization resulted from the efforts to establish the American public school system and enforce the teaching of English. The turn of the century American schools were dominated by the Progressive idea of an expert and centralized authority guaranteeing a modern and standard educational system (Tyack, 1993). The Progressives' notions of educational administration made their way into the Puerto Rican school system through Commissioner Brumbaugh's organization of the Education Department. The task in Puerto Rico was daunting, since there was no central public school system or general educational policy inherited from the Spanish government, teachers were paid by their communities and many of them lived in the schools, and illiteracy was rampant (around $80 \%$ ). In order to handle the new and tough challenges, the resulting system was one in which most decisions were taken at the highest level. The 
incipient system lacked effective communication and participation channels for teachers and communities, which allowed Commissioners to make swift policy changes, including decisions unpopular with large sectors of the general public and the teaching body [11].

The educational system was divided among school districts and school boards (juntas escolares), both directed by superintendents who answered directly to the Commissioner. Superintendents evaluated the teachers' work and made recommendations for their reappointment to the Commissioner, who made the final decisions. Before the school laws of 1901, the local school boards had a significant influence in the operations of the school system, particularly since board members could hire teachers without requiring central approval. The creation of the Education Department under the Foraker Act, and the 1901 school laws, eliminated most of the institutional mechanisms for school board influence and thus, the main instrument for community involvement in educational policies.

Finally, there were several English supervisors, who informed the central office about the progress of English instruction, and taught English to Puerto Rican teachers (Osuna, 1949; Solís, 1994). Ultimately, while there were several subunits in the educational system, most policy and administrative decisions emerged from the Commissioner's office. The relatively small size of the island's educational system contributed to the feasibility of such a centralized operation [12]. In contrast, the American educational system in the Philippines, which went through a comparable phase at the same time, was much larger and provided incentives for a relatively more decentralized structure. There were about 75 towns in Puerto Rico, while there were some 1,600 in the Philippines, and the Filipino school districts exercised more discretion on policy decisions than their Puerto Rican counterparts (Barrows, 1907). The comparison is relevant since both educational systems were products of the United States' colonial experiment, and it shows that, while both approaches intended to create American school systems, the specific shapes of the school systems were influenced by domestic societal and political conditions.

The duties and influence of the Education Commissioner transcended the school system. His membership in the Executive Council made him a powerful figure on general policy-making processes. Moreover, the Education Department commanded a large percentage of the government's budget, ranging from twenty five to thirty seven percent annually, which made it the government agency with the largest percentage of the total budget, and the Education Commissioner one 
of the most powerful members of the Governor's Cabinet and the Upper House of the legislature.

The Commissioner's participation in legislative affairs involved the Education Department in insular politics. On the one hand the Commissioner was isolated from Puerto Rican politics because he was chosen in Washington, without confirmation from the Puerto Rican legislature. However, the Commissioner's membership in the Executive Council involved him in the political bargaining of legislative processes. This bargaining implied that he needed to draw some support for his policies from cabinet members and elected politicians in the House of Delegates. Hence, the Commissioner of Education was a strong political figure that nevertheless became vulnerable to political pressures from legislators and other cabinet members. Ultimately, while educational decisions were made at the top levels of the Education Department, non-educational government agencies had influence over educational policies. This allowed for the involvement of outside language entrepreneurs in educational policies.

Most Puerto Rican teachers opposed the emphasis on English instruction but initially failed to translate their demands into public policy. Reactions from children's parents and community members had limited institutional venues to influence policy, mostly through public opinion, local school boards, or legislative leverage. This explains in part the popularity and dominance over the Puerto Rican legislature between 1904 and 1928 of the Partido Unión, which opposed the imposition of English in schools. In fact, it has been argued that the movement against teaching in English was part of a larger struggle for autonomy, because English as instructional medium was understood to be part of the non-democratic institutions created by the Foraker Act (Algren de Gutiérrez, 1987).

\section{The Falkner Language Policy, 1904-1916}

Roland Falkner became Commissioner of Education in 1904 and established a new language policy in the academic year of 1905-1906. The emphasis on English instruction, initiated by Eaton in 1899, grew in new and larger proportions under Falkner's administration. English became the medium of instruction in all classes starting on second grade. Rural schools, poorer than their urban counterparts and lacking enough teachers trained in English, experienced the transition at a slower pace. Falkner's tenure lasted only until 1907, but his policy extended until 1916 with the next three Commissioners, Edwin Dexter, Edward Bainter, and Paul Miller. Falkner's emphasis on English came at the expense of Spanish, which was reduced to one class period. The approval of the New School Laws in 1905, product of Falkner's 
legislative efforts in the Executive Council, made it mandatory for Puerto Rican teachers to pass annual English exams, without which teaching licenses would not be granted.

Initially, adverse reactions towards Falkner's policy were moderated by a unique political juncture that allowed him to forge an alliance with important members of the Puerto Rican political elite. Before Falkner's tenure, Commissioners Brumbaugh (1900-1901) and Lindsay (19011904) had provoked hostile public reactions from Puerto Rican politicians and educators by their emphases on English instruction and Americanization tactics. Also, the limited Foraker Act had not quenched the claims for self-government that most Puerto Ricans believed would accompany the United States' sovereignty. In an effort to manage the island's negative public opinion, United States' President Theodore Roosevelt named Beeckman Winthrop Governor of Puerto Rico (1904-1907). Winthrop cultivated good terms with the leaders of the newly formed Partido Unión, in favor of some form of self-government and recognition of the Puerto Rican culture (Negrón de Montilla, 1990; Bayrón Toro, 1984) [13]. The Partido Unión held control of the legislature from 1904 to 1928, and Winthrop placed several of its leaders in high government posts. Consequently, while opposing Americanizing strategies, the Unionistas moderated their criticisms against Falkner's language policy. The opposition party, the Partido Republicano, protested the Unionistas's little influence within Governor Winthrop's cabinet. However, the Partido Republicano's position as defender of the Puerto Rico's inclusion in the United States federation prevented their opposition to Falkner's Americanizing tactics, which they considered necessary to facilitate annexation. Hence, during Falkner's tenure, his language policy did not face the kind of hostility that other Commissioners encountered.

Commissioner Edwin Dexter (1907-1912) continued and intensified Falkner's policy, stressing English instruction in rural schools, extending the use of English as the medium of instruction to first grade, and eliminating Spanish courses from the first grade curriculum. Dexter's tenure coincided with the peak of the Partido Unión's power after a landslide victory in the 1908 legislative elections. By then, the new Governor Regis H. Post had effectively terminated the alliance with the Unionistas because of their vocal disappointment with unfulfilled expectations of increased self-government.

The opposition to Falkner's policy grew during Dexter's management. The Asociación de Maestros de Puerto Rico (AMPR), took the elimination of English as the medium of instruction in schools as its main campaign, and forged an alliance with leaders of the Partido Unión. The AMPR represented a widespread concern: the individual 
costs on teachers in terms of time and resources for learning English and adapting to the newly imported teaching methods [14], and the anti-pedagogical nature of the English language policy.

The resistance to Falkner's policy reached its zenith during Edward Bainter's tenure (1912-1915). By then the English language policy had become a major public debate, known as el problema del idioma or the English question. Bainter maintained the language policy virtually unchanged. The AMPR's links with the Partido Unión were confirmed after the former's general assembly in December 1912, which agreed to petition legislation from the House of Delegates favoring the use of Spanish in schools. In 1913, resulting in part from the AMPR's efforts, the House of Delegates approved a bill establishing Spanish as the language of instruction in elementary schools (which extended to eighth grade), and a bill eliminating the annual English requirement for teaching licenses. The strongest opposition to the House bills came from Representative Juan B. Huyke, who later became Commissioner of Education. The Executive Council vetoed the language bills, effectively maintaining Falkner's policy. The House approved another language bill in 1915, which strived to make Spanish the language of instruction and of the courts, only to be vetoed by the Executive Council again. Although no other language bill would pass in either legislative chamber until 1946, the language debate remained linked to the larger questions of national identification and colonialism.

\section{Language entrepreneurs, 1904-1906}

The relevant language entrepreneurs were defined during Falkner's era. The political and institutional structures created at the beginning of the century created the mechanisms for involvement in policy formation and established the rules by which educational and political actors would play during the first two decades of the twentieth century.

\section{Teachers}

The conditions of the teaching profession in Puerto Rico during the Falkner policy included low job security, low pay, reduced classroom autonomy, and no national teachers' union (until 1912). Those conditions created biases against teachers participating in the process of formulating policy, by making participation more costly than abstention.

\section{Job security}

Puerto Rican teachers' gloomy job security expectations between 1905 and 1916 were caused by four factors. First, there was no 
systematic process of merit for hiring and promoting teachers. Superintendents recommended hiring while the Education Commissioner determined the final decisions. Evaluations of job performances depended on superintendents' and Commissioners' perspectives, which allowed for arbitrary and discriminatory decisions. For instance, Commissioner Miller stated in 1919 that he would not hire any university graduate who sympathized with the proindependence ideology (Negrón de Montilla, 1990:185). Second, teaching licenses were granted on temporary bases, so renewals or reappointments could be denied relatively easily. Thus, teachers who did not follow the Education Department's official policies risked not being hired or not having their licenses renewed. Third, the annual English exam put a new burden on teachers. While they received some incentives to learn the language, such as time off and commendations, teachers were mostly burdened with the new requirements. They were expected to study the language after school hours, and to receive lessons from American English teachers during weekends and summer months. Besides the additional work, time dedicated to learning English could not be dedicated to other profiting enterprises, such as summer and weekend jobs, which many teachers needed to compensate for their low salaries.

There was a lack of teachers who could fulfill the language requirements, which prompted the fourth element that jeopardized job security: the replacement of Puerto Rican teachers by American teachers. The importation of teachers increased the competition for the best jobs, since most of the highest paying posts were in high schools and special English posts, which required English proficiency.

\section{Teachers' wages}

Teaching salaries were low and the lack of a teachers' union precluded wage collective bargaining until after 1912. Puerto Rico suffered from high unemployment levels, prevalent illiteracy (around $70 \%$ ), and a struggling economy. The teaching profession reflected those conditions in several ways. First, overall economic conditions offered few employment choices, so a low-paying teaching job was better than no job at all. Second, large migrations from the mountainous countryside to the coastal urban centers redefined the school's place within the community. The status of teachers evolved from respected (even if meagerly paid), central members of their communities, into anonymous government employees in large and rapidly changing urban communities. 


\section{Classroom autonomy}

The level of classroom autonomy, traditionally high under the Spanish school system, was reduced by the centralized American school system. The establishment of the English Supervisor posts (occupied by American teachers) added a new level of teacher supervision. Also, Commissioners' circular letters specified how to run language courses, from textbooks to time allotments to daily homework. This is not to say that teachers did not have flexibility within the boundaries of their schools, particularly in remote rural schools that received little supervision. Nevertheless, their autonomy was reduced in relation to what they were accustomed.

\section{The Asociación de Maestros de Puerto Rico (AMPR)}

The Puerto Rican educational system offered strong incentives against teachers' collective action. Teachers struggled to create a union since at least 1900, but it was not until 1912 that the Asociación de Maestros de Puerto Rico (AMPR) emerged.

Among the AMPR's main objectives were to produce legislation that would systematize the hiring process, to establish Spanish as the instructional medium [15], to increase the school year from nine to ten months (and with it the teachers' pay), to increase teachers' salaries, to establish permanent licenses (tenure), to produce legislation in favor of a pension system, to create scholarships for teachers, and to establish a set number of paid absent days (Rodríguez Bou, 1960:400). Those objectives reflected two broad concerns: material improvement of the teaching sector, and change of the educational language policy.

After its creation, the AMPR exerted influence in educational issues through the House of Delegates, especially during the Partido Unión's dominance between 1904 and 1928. The influence was most evident in the language bills approved in 1913 and 1915. Although the bills did not pass, they had a direct impact on the island's public opinion and on the educational policies following the Falkner period.

Commissioner Miller was influenced by the legislative efforts to reduce the role of English, and even Commissioner Huyke, a fervent supporter of English in schools, did not reverse Miller's changes.

\section{Involvement in policy formation}

Policy formation rested almost entirely in the hands of the Education Commissioner, with no institutional channels for teacher involvement, so their interests were all but excluded from school policies. Many of 
the conditions discussed by scholars of educational administration, which discourage teachers from participating, were present in Puerto Rico: increased time demands, loss of classroom autonomy, and threats to career advancement (Duke, Showers, and Imber, 1980). However, there were alternative forums for teachers' expression. Teachers could influence public opinion through the written media and through Puerto Rican political parties. Later, the AMPR became the main exponent of teachers' interests and utilized the same forums that teachers had been using on individual bases since 1899.

\section{Administrators}

In 1900, a centralized educational system was created through the provisions of the Foraker Act. Osuna (1949) divides the system in three parts, based on the relative distance from the central organisms: a central administration, local levels close to communities, and a medium level linking the central and local tiers. Using Osuna's categories, administrators' interests are divided here among those of the central office, the supervisors, and the local school boards.

\section{Central office}

The Foraker Act placed the administration of education in the hands of the Commissioner, but did not detail his duties. Specific powers were assigned in successive legislation, especially through the school laws of 1901. These laws centralized further the administration of schools, placed great powers in the hands of the Commissioner, and subordinated the school boards to central office jurisdiction.

Education Commissioners' main goals were to develop and manage a new school system efficiently, to establish an American style of school system, and to alter cultural habits through a new language and a new national identity. The daunting task of developing a new school system proved one of the greatest achievements of Puerto Rico Education Commissioners. In 1898 Puerto Rico had 525 public schools, 765 teachers, and 29,172 children in attendance. By 1914, there were 4,336 public schools, 2,564 teachers, and 207,010 children attending schools (Bainter, 1914:372).

The biggest challenge for central administrators came from their attempt to foster American cultural values and habits [16]. Two aspects were salient in this process: patriotism and language. Most writings of the time indicate that the school system was successful in establishing a sense of identity (if superficial) with United States' nationalistic symbols (flag, anthem, and such), historical figures (particularly Washington and Lincoln). Children were required to salute 
the U.S. flag, learn the "Star Spangled Banner," recite the Pledge of Alliance, and study U.S. presidents as if they were part of their shared history.

The second aspect, that of language, was more controversial. Not to say that there were not public outcries against instilling American patriotism, but at that moment, they paled compared to the language issue. Language became the symbol of relations between Puerto Rico and the United States. Societal sectors that rejected the use of English as instructional medium became associated with autonomist and independence ideals, while those in favor of English became associated with statehood preferences (Cebollero, 1945). Moreover, Education Commissioners' efforts to make children learn English affected the growth of instruction in other areas, a fact that was asserted by several educators in and out of the island (International Institute of Teachers College, 1926).

\section{Supervisors}

The middle level of administration underwent several changes, although the nature of the post was maintained. Supervisors represented the link between the Commissioner and local communities (school boards, municipalities, and individual schools). The first supervisors were English supervisors, hired in 1899 to oversee the progress of English instruction. They were all U.S.-born, English-speaking individuals. English supervisors held teachers' meetings for instruction in English and methods, distributed their salary checks, gave license examinations, rendered monthly reports about schools' conditions, and acted as direct representatives of the central office (Osuna, 1949:144-5). Supervisors' were heads of their school districts and their loyalties lied with the central office. Not surprisingly, they met resistance form teachers, who were not accustomed to direct supervision and resented the imposition of a new language and method.

After 1913, new supervising positions were added, to include Spanish, manual training, domestic science and household economy, and playgrounds and athletics supervisors (Osuna, 1949:147). Supervisors were appointed by the Commissioner, who consulted them on strategies for implementing language policy. Their work was very important in the implementation of Commissioners' policies, and whatever success Falkner's English policy achieved was in great deal due to the supervisors. On several occasions, Falkner asked Superintendents for progress reports on their districts' English instruction, statistics on English teachers, and specific information 
about English teachers' placements within their districts. These letters and instructions reflected the strong pressure that supervisors faced.

\section{Local school boards}

The first school laws of 1899 established that each municipality would have a school board, composed of three trustees, elected during municipal elections. School boards' duties at that time included nomination and employment of rural and graded teachers, principals and janitors for their schools, and holding, under their corporate names, land and property for school purposes (Osuna, 1949:150). Supervisors were ex-officio members of the boards, with voice but no vote, and shared with the boards the decisions over assigning teachers to schools. On one level, school boards were administrative posts that helped establish the new educational system. On another level, school boards were elective organisms that represented communities' interests and were directly influenced by politics. Teachers' influence over school boards decision-making was low, as evidenced by the large number of teachers that were fired each time a new party controlled the municipal elections. The decentralized nature of school boards did not preclude the exclusion of teachers at local levels.

School board members' interests differed throughout the island but, being elected posts, their preferences reflected the popular consent. During Falkner policy's tenure, the Partido Unión controlled most of the island's municipalities and school boards. Since the party was openly against English as instructional medium, most school boards protested Falkner's policy. The fact that Education Commissioners addressed their circular letters to school boards in Spanish, while supervisors were always addressed in English and teachers mostly in English, showing an admission from Commissioners that most school boards resented the use of English.

School boards lost a great deal of power with the Foraker Act and especially with the School Laws of 1901. Their participation in school policy decreased as the decision-making core shifted towards the center. The reduction in school boards' influence decreased the communities' inherence in educational policies and eliminated an important obstacle against the intensification of the English language policy.

\section{Parents}

Understanding the involvement of parents in Puerto Rico's school system between 1904 and 1916 presents the challenge of lacking 
information on the topic. Very little of the literature addresses the issue, and most refers to the latter stages, after parents' organizations were created (Rodríguez Bou, 1960:2362). Also, parents received scarce attention in the Education Department's internal correspondence. However, after exploring the state of affairs in Puerto Rican society in 1904, two potential forms of parental involvement can be derived, namely local school boards and parent-teacher associations.

School Boards' main and last real source of influence came through teacher placement, which was often used to grant political favors to loyal teachers. This was true because the political party that controlled the municipality also controlled the school board. School boards controlled by Unionistas were against English as instructional medium, while those controlled by Republicanos and Socialistas were likely to favor the use of English (Morris, 1995:24). From 1904 to 1917, the Partido Republicano controlled from 22 to 34 percent of the municipalities, while the Partido Unión controlled from 66 to 78 percent. The Partido Socialista, a workers' party identified with annexation, won 8 percent of the municipalities in 1917 (Bayron Toro, 1984). Thus, from two thirds to three quarters of the school boards were against Falkner's policy, while from one quarter to one third favored it. If school boards had real influence over policy in their jurisdictions, the use of English in schools would have varied according to municipalities. It did not.

The second form of parental involvement, the parent-teacher associations (PTA's), originated in 1914, with the Asociación de Madres of The University of Puerto Rico's Model School (Rodríguez Bou, 1960:2363). By 1916, similar associations had emerged throughout the island. The parents-teachers associations remained independent until the creation of the Liga Insular de Asociaciones de Padres y Maestros in 1924 (Rodríguez Bou, 1960:2363), which included private and public schools' PTA's. The original goals of PTA's focused on supporting schools' efforts in their children's education, rather than on influencing policy. According to arguments presented earlier, parents' participation in school affairs typically begins as a reaction to their children's poor performance (Fine, 1993). In 1914 Puerto Rico, school dropout rates were large and graduation rates were small [17], so parents' expectations of public schooling remained mostly unfulfilled. PTA's in Puerto Rico emerged as parents' reactions to such problems.

Section two proposed that parents have two main interests in terms of language preferences: social mobility and group identity reproduction. Social mobility considerations provided incentives for Puerto Rican 
parents to support an extensive use of English in classrooms. This was especially true for higher-income sectors, whose children had the best opportunities to take advantage of their English skills in the job market. Such skills were most helpful on government jobs and within teaching ranks. Both types of jobs required higher than average educational levels, and, in the former, social status and family connections were most helpful. However, in spite of differences on social mobility expectations, all socio-economic sectors believed that their children would be better prepared for the future with a strong knowledge of English. As for group identity issues, political considerations had strong effects on language use preferences. Since the English question became linked to political relations with the United States, those sectors favoring annexation supported a stronger presence for English than those supporting autonomy or independence.

The high centralization of the school system did not allow for the input of parents' preferences over educational policies. A decentralized and participatory system would have filtered parents' influence through school boards and local PTA's. Regional variations in the use of English and Spanish would have occurred. In a centralized but participatory system, parents' input would have come through a central PTA. It is likely that central PTA would have followed the Unionistas's line, since the party's overwhelming control of the House of Delegates denoted a national majority in favor of its interpretation of Puerto Rican identity that led to the rejection of Falkner's English policy.

\section{Political parties and politicians}

The politicians with the deepest involvement in educational language politics during Falkner's policy were the leaders of Partido Unión, who maintained control of the legislature from 1904 to 1928. The party's preference towards language policies and its influence on policy remained constant during the Falkner period. The opposing language entrepreneurs, the Partido Republicano and Partido Socialista, supported the existing emphasis on English. However, the policy was not established thanks to their influence on language policies, but rather in spite of their lack of influence. The centralized and nonparticipatory nature of the Education Department limited these parties' influence over language policies.

\section{Institutional causes of Falkner's Policy}

Falkner's policy gave English a fundamental role in education while it played a minimal role in daily use. The explanation lies within the 
three institutional features of the Education Department between 19904 and 1916. The features were centralization of decision-making, minimal participation from teachers and parents, and exposure to political pressures. This specific combination of conditions allowed for the establishment of an educational language policy based on the preferences of top tier educational administrators.

The centralization of decision-making was the most salient characteristic of the Puerto Rico Education Department. A centralized structure allowed the Commissioner to make quick decisions with little consideration to its clients' short-term demands. This dimension drew adverse reactions from teachers and parents, but their influence was curbed by the limited participation channels within the Department and the non-democratic nature of the governing institutions established by the Foraker Law.

Another feature of the educational system in Puerto Rico was the lack of participation channels available for teachers and parents in policy formation. The main area of expression was through public opinion in newspapers, and through alliances with political parties. The concentration of power in the hands of the Commissioner, particularly in terms of hiring and promoting of teachers, served as an effective deterrent for teacher involvement. Since hiring and promotion of teachers was not done on a systematic merit basis, those who voiced criticisms risked losing their jobs. Hence, there were structural obstacles against teachers' participation in educational policies.

The third characteristic of the Puerto Rico Education Department was that its Commissioner participated in the island's colonial administration through his involvement in the Executive Council, which provided the Education Commissioner with influence beyond the school system and made him a powerful political figure. However, it also involved the Commissioner in political bargains to approve legislation, which politicized the post and allowed some societal sectors to exercise influence over the Commissioner's decisions. Those sectors included influential politicians who rejected Falkner's English policy, particularly leaders of the Partido Unión. Hence, while the Education Department had limited participation channels for teachers and parents, the Commissioner's involvement in legislative politics opened spaces for the introduction of a limited number of preferences from teachers and community members. This pattern became clearer after the creation of the AMPR and its alliance with the majority Partido Unión.

In sum, the educational language policy established by Falkner in 1905 was dominated by the preferences of a central educational 
bureaucracy, whose main interest was the efficient establishment of a uniform language policy, broadly defined by the metropolis' goals of cultural assimilation. Education Commissioners' interest in establishing Americanizing policies was dictated by factors outside the realm of Puerto Rican educational institutions, since they were named by United States Presidents with such intentions. But Commissioners were able to implement a sweeping language reform that affected adversely several Puerto Rican societal sectors due to the exclusion of such sectors from educational policy.

\section{The Miller Huyke Language Policy, 1916-1934}

The political background behind the creation and endurance of the Miller/Huyke educational policy was dominated by four related developments: First, the public debate generated by various bills presented in the U.S. Congress that contemplated the extension of U.S. citizenship to Puerto Rico's residents; second, the increased mobilization and participation of teachers, through the AMPR's influence on public opinion and legislative efforts; third, the growth in Puerto Rican nationalism, which permeated the educational system through the mobilization of parents and students; fourth, the Second Organic Act (or Jones Law) of 1917, which amended the organization of the colonial government, restructured Puerto Rico's educational institutions, and extended U.S. citizenship to Puerto Ricans.

The years before the establishment of the Miller/Huyke policy were marked by a heated public debate regarding the redefinition of the colonial administration in Puerto Rico. There were significant differences about the practical definition of self-government, but all agreed on the undemocratic nature of the Foraker Act and the need to clarify the citizenship status of Puerto Ricans. A series of Congressional bills made it imminent that U.S. citizenship would be extended to Puerto Rican residents. Large sectors of the Puerto Rican population welcomed the possibility of U.S. citizenship, and the three leading parties, Partido Unión, Partido Republicano, and Partido Socialista, supported it. It was evident in the island's public opinion that some sort of change was soon to emerge from Washington. The prospects for change transcended the political arena and extended to the educational front. Hence, many people expected modifications to Falkner's educational policy as well.

Paul Miller's appointment as Commissioner of Education in 1915, coupled with the citizenship question, created expectations and concerns about new educational language policies. On the one hand, citizenship could imply greater legal equality with U.S. residents. On the other hand, it could fuel greater efforts towards Americanization. 
The naming of Miller was fundamental in creating positive expectations because he had been involved with Puerto Rico's school system since 1898 and was not perceived as an outsider by teachers and the community at-large.

The second political development that influenced Miller's policy was the increased participation of the AMPR in educational policy. The AMPR continually pressed legislature to approve bills that would replace Falkner's policy with one emphasizing Spanish. While unsuccessful in replacing Falkner's policy with their own, the AMPR succeeded in reducing the emphasis on English. This influence by teachers had been unlikely before the establishment of a collective body of action.

Another major development was the rise of Puerto Rican nationalism, which permeated the public school system against the Department's Americanizing practices (Morris, 1995; Negrón de Montilla, 1990). The conflict assumed ideological tones with various attempts to raise the symbols of Puerto Rican nationalism (like the single-star flag) during official school ceremonies, provoking repressive reactions from Commissioners Bainter and Miller.

The last major political event of the period considered here was the approval of the Jones Act by the U.S. Congress in 1917. This law reorganized the island's government by eliminating the Executive Council, creating a popularly elected Senate, renaming the House of Delegates as House of Representatives, and extending U.S. citizenship to Puerto Ricans. The Governor and the Commissioner of Education remained appointed by the U.S. President. The office of Resident Commissioner was left intact. The Jones Law affected the Education Department's centralization in two ways. First, it reduced the centralization by limiting the Commissioner's leverage over public policy. Second, it formalized the hierarchical structure established during the Foraker Law era.

The reduction in the Education Commissioner's influence on general policy resulted from the dismissal of the Executive Council, which decreased the former's political clout by terminating his capacity to enact educational policy through legislation. After the Jones Act, any educational legislation would have to be processed through third persons in the popularly elected legislature. This third-person legislation increased the bargaining leverage of domestic politicians over Education Commissioners, and indirectly improved the influence on educational legislation and policy of groups that had access to those domestic legislators. One such group was the AMPR, whose alliance with the Unionistas allowed them to take a more active role in 
educational policies. On the other hand, the Jones Act increased the formal centralization of the Department, but decreased it in real terms by clarifying the limits of the Commissioner's duties (Negrón de Montilla, 1990).

Paul Miller's appointment as Commissioner of Education was welcomed by the AMPR, the Unionistas, and the Republicanos because it ended Commissioner Bainter's polemic tenure and offered hope for a different tone in the Education Department.

In 1916 Miller established a new language policy, in which Spanish would be the medium of instruction for most classes until fourth grade. Fifth grade would include classes in Spanish and English, while grades sixth and higher would have English as the medium of instruction, except for Physiology and Spanish. The Miller policy reversed Falkner's policy, but stopped short of the AMPR's and Partido Unión's goals of using Spanish as the instructional medium until at least high school.

Miller's honeymoon with the teachers' union came to an end after his new policy failed to meet the high expectations from the AMPR. The AMPR criticized Miller's policy in their 1917 Annual Assembly and approved a resolution demanding the use of Spanish as instructional medium in all grades (Negrón de Montilla, 1990:173), which provoked a public response from Miller justifying his changes. While the tone of the public discussion was deferential, the fundamental differences were clear.

Another source of friction for Commissioner Miller was the rise of Puerto Rican nationalism. Students demanded the rise of the singlestar Puerto Rican flag (a symbol of separatism) in several high school graduation ceremonies, which antagonized the Education Department's practice to emphasize United States symbols and motivated Miller to suspend several students. Reactions against the suspensions included student strikes and teacher activism (Morris, 1995; Negrón de Montilla, 1990). Miller suppressed the student strikes and made public that the Department would hire no teacher supporting the independence movement. Miller's strong hand tactics curbed much of the teaching activism, but provided a reason for popular sympathy towards the AMPR's postures.

Juan Huyke became Commissioner of Education in 1921. While the volume and tone of Huyke's expressions about the need to learn English appeared almost obsessive, the curriculum was not changed 
substantially. He also continued Miller's practice of not hiring teachers who identified openly with the independence movement.

\section{Language entrepreneurs: 1916-1934}

The period before and after the establishment of the Miller/Huyke policy experienced an increase of teacher, student, and parent participation in educational affairs. This rise, coupled with a slight movement away from absolute centralization, allowed language entrepreneurs that opposed Falkner's policy to influence the establishment and maintenance of a new policy. Thus, the Miller/Huyke policy emerged from a reordering of power dynamics combined with a relocation of decision-making locus.

\section{Teachers}

The creation of the teachers' union became the single most important development between 1915 and 1930. The AMPR provided incentives for participation and became an important language entrepreneur.

\section{Job security, wages, and classroom autonomy}

There were no significant changes in teachers' job security from the Falkner era. After 1914, budgets were reduced due to a contraction in demand for exports during the First World War, which reduced the Puerto Rican government's spending capacity, cut teaching positions, reduced salaries, and heightened competition.

Besides salaries and number of jobs, the school system lacked a uniform classification structure. Supervisors appraised teachers' jobs according to a scale, but with no consistent evaluation criteria, which allowed for arbitrary evaluations and inconsistent standards among the various school districts, and encouraged a caste system rather than a unified professional group (Osuna, 1949:180). It is no surprise that among the AMPR's priorities was the creation of consistent and systematic classification guidelines.

The relevance of low job security and salaries for this study lies on the negative impact on teachers' participation. However, measuring from the involvement in the AMPR, teacher participation increased. This increase can be explained in Duke, Showers, and Imber's (1980) terms, as a reaction to the perception of increase in real influence from participation. Such a perception derived from the willingness of Education Commissioners to court the AMPR. Whether the courting responded to a co-optation attempt or to a genuine interest in responding to teachers' interest, the teachers' union was taken 
seriously by the central office from its inception, which eased teachers' fears of joining the organization.

In terms of classroom autonomy, Education Commissioners intensified their specific course instructions, especially after the introduction of new texts or methods. The days of teacher individualism under the Spanish rule were long gone, and teachers became accustomed to receiving detailed guidelines from the central office.

One incentive to join the AMPR was the prospect of regaining some indirect control over classroom operations, since the teachers' union could potentially influence teaching methods, textbooks, and curricula. Under most circumstances, teachers' involvement jeopardizes classroom autonomy since it opens spaces for greater scrutiny by peers and administrators over their classroom activities. Hence, the concern over ceding classroom autonomy typically functions as a deterrent for involvement in policy-making. In the Puerto Rican case, however, participation had the potential of increasing autonomy, since most teachers already had little say over their daily work, while the AMPR's involvement gave them a voice in curriculum development at the central level.

\section{The Asociación de Maestros de Puerto Rico (AMPR)}

Miller's cordial relations with the AMPR allowed him to influence the organization's goals in three directions. First, Miller encouraged the AMPR to join ranks with the National Educators Association (NEA), which would reduce the possibility of anti-U.S. postures in the teachers' union. Second, Miller attempted to influence the AMPR into focusing on theoretical pedagogical issues, rather than on policy affairs. Miller created The Puerto Rico School Review, a monthly journal that informed teachers about new developments in Puerto Rico's public education. The Puerto Rico School Review also avoided policy issues and encouraged teachers' conferences that emphasized teaching methods rather than general curriculum development or evaluations of teachers' job conditions. Finally, the inclusion of teachers' inputs on certain limited areas provided a sense of ownership to the AMPR that reduced adversarial tendencies.

Cordial relations moderated, but did not preclude, confrontations with the AMPR. Concerns for teachers' low salaries and insecure tenure were frequently presented for consideration at the House of Delegates, with modest results. On the language question, the AMPR pursued or supported three legislative bills aimed at establishing Spanish as a dominant language in schools and other areas. The balance of power of educational policy-making remained tilted towards 
the central office side, but the inclusion of an organized pressure group of teachers concluded the Education Commissioner's absolute control over school policy.

\section{Administrators}

When Paul Miller assumed the leadership of the Education Department in 1915, the organization of Puerto Rico's school system differed little from the period of Falkner's policy. Miller's Department of Education continued to function as a highly centralized institution with few participation channels for teachers and parents. However, there were some important differences between the conditions surrounding Falkner's and Miller's school systems. By 1915, two educational sectors were increasing their inherence over educational policies: teachers and parents.

\section{Central office}

The emergence of Miller's policy was affected more by changes in participation than in decentralization. Nonetheless, the increase in decentralization brought about by the Jones Act a year after the establishment of Miller's policy obstructed a reversal of the policy by Commissioner Juan B. Huyke (Negrón de Montilla, 1990).

The Jones Act truly reduced the Commissioner's influence through the elimination of the Executive Council and, hence, the Commissioner's legislative role. It terminated the direct formal inherence on educational affairs of other government agencies and reduced the Commissioner's overall political weight. Huyke did not return the educational language policy to Falkner's approach because the Education Commissioner had lost enough political power and ground to the AMPR in the area of policy formation. Reverting Miller's policy would have been too costly.

\section{Supervisors}

The supervisory position changed little during Miller's tenure. Supervisors still represented the link between the Education Department and local communities. While Miller did not modify the nature of the position, he increased the ratio of native vs. imported supervisors, which improved relations with teachers. This aspect grew important as the AMPR became increasingly involved in educational legislation and, consequently, in educational policy-making. 


\section{Local school boards/Municipal commissioners}

Local school boards were administered under the direction of the Division of School Boards Accounts. They disappeared in 1919 and were replaced by Municipal Education Commissioners, with one officer for each municipality. The town mayor, with the advice and consent of the municipal assembly, appointed each Municipal Commissioner, later renamed School Director (Osuna, 1949:280).

\section{Parents}

Parent and student activism experienced an increase in 1915 as a result of a series of unsuccessful language bills presented in the House of Delegates since 1913. The unprecedented student and parent activism placed great pressure on Commissioner Miller to revise the Falkner language policy. Miller's reaction to the increased mobilization of the school system's "clients" was prompt. The next academic year began with a substantial reduction of the use of English. The new policy served to temporarily appease adverse public opinion by providing those language entrepreneurs who opposed Falkner's policy with a partial victory. Spanish would not be the instructional medium for all grades, but at least it would be so until fourth grade, a significant departure from Falkner's use of English in all grades.

Miller's quick reaction and his modification of the language policy allowed him to cultivate an amicable relation with parents associations. In fact, several circular letters applauded the formation of PTA's and encouraged supervisors to support their growth. To be sure, Miller defined the PTA's as supporters of the Department's efforts rather than as partners in developing policies, but that PTA's were welcomed illustrates their reconciliation with the central office.

\section{Political parties and politicians}

The Partido Unión became a major player among language entrepreneurs, and its alliance with the AMPR was considered an important tactic to lure the teacher vote. Teachers were a considerable proportion of the public employees, and possessed credibility based on their academic preparation. The electoral and legislative alliance between Unionistas and the AMPR was based on the former's capacity to influence policy and government structures, and the latter's ability to produce votes and a respectable public opinion. 
Also, the eclectic ideological base of the Unionistas, which at one point included all three status alternatives, was a constant source of centrifugal forces. The language question provided the party with one single, pivotal issue that could provide cohesion. In terms of education in general, the Partido Unión's position reflected its claim for increased self-government, from the Foraker Act through the Jones Law to the eventual Law of Elective Governor of 1947. One major element in obtaining self-government was decentralization, understood as greater participation from domestic sectors in the Puerto Rico's government. Within this context, the Partido Unión's leadership saw the Education Department's centralization as reflective of the undemocratic nature of the island's government, and fought to reduce the Commissioner's power, particularly in terms of hiring and promoting teachers (Pagán, 1972; Algren de Gutiérrez, 1987).

Leaders of the Partido Republicano maintained a supportive attitude towards Falkner's and Miller's policies. Not surprisingly, they also supported the extension of United States' citizenship to Puerto Ricans in 1917, which they understood as a step closer towards becoming a state. Republicanos, however, agreed with Unionistas in the need for increased self-government. In this sense they agreed with Unionistas in pressing for decentralization of the island's government. Both parties also agreed on the need to curb the Education Commissioner's powers; the Partido Republicano approved a resolution in their 1917 assembly requesting a change in the island's political institutions, which included making the Education Commissioner more accountable to the elected legislature (Algren de Gutiérrez, 1987:80).

The third political force in the island, the Partido Socialista, did not oppose the Americanization through education because of its prostatehood platform and because its power base did not include teachers. Its followers were mostly affiliated to the Federación Libre, composed mainly of tobacco and sugar cane workers (Morales Carrión, 1983). Its efforts concentrated on tensions between workers and plantation owners, and issues of centralization and selfgovernment remained secondary.

\section{Institutional causes of Miller/Huyke's Policy}

The change in educational language policy established by Miller in 1916 resulted in a reduction of the use of English. The societal use of English increased during the Falkner period mainly because of a growth in economic and political integration with the United States, which increased the number of English-speakers in the island and the jobs requiring English skills. The increase in English social use also shows how Falkner's policy achieved, to a limited extent, its goal of 
transforming Puerto Rico into a bilingual society. From 1904 to 1916 , the number of people who could speak English in Puerto Rico increased from less than 3 percent to 9 percent (a growth rate of over two hundred percent). Conversely, the educational use of English after 1916 experienced a reduction in emphasis, from English as the instructional medium for all school years to its use beginning in fifth grade.

Miller's policy reform provides a good illustration of the political nature of educational language policies. A rise in participation of language entrepreneurs opposed to the existing educational policy preceded the new policy's creation. More specifically, the teachers' union, parents and students assumed different but active roles in demands for policy revisions. The AMPR's influence on educational policy rested on the organization's large membership, on its partnership with the leading political party, and on its partial co-optation by the Education Department. Large membership levels generated a large capacity to mobilize and influence public opinion, which in turn provided incentives for Education Commissioners and the Partido Unión to consider the organization seriously. The AMPR's alliance with the Partido Unión entailed a strong presence in central legislative affairs and a direct challenge to the Education Commissioner as legislator. Commissioner Miller, however, demonstrated competent political skills in avoiding outright confrontations with the AMPR by opening communication channels, encouraging membership with the NEA and the AMPR, allowing a limited participation from the AMPR in peripheral policy issues, and adapting his policies to AMPR's demands. The reduction in emphasis on English use was greatly influenced by the effective pressures that the AMPR was capable of placing on Miller through internal and external means.

The growth in number of parents and students involved was the product of a spontaneous reaction to Education Commissioners' policies and to changing national political dynamics. That Miller took the schools system's "clients" mobilization as a serious threat is evidenced by his swift repressive measures.

The maintenance of Miller's policy by Commissioner Huyke deserves special attention because Huyke had defended Falkner's policy during his tenure as President of the House of Delegates, and had opposed bills establishing Spanish as the instructional medium. Two factors prevented Huyke from reverting Miller's policy: first, the institutionalization of the AMPR's inherence in Departmental affairs, which provided it with an effective veto against unwanted policies; second, the slight decentralization brought to the Education Department by the Jones Law, decreased the general power of the 
Education Commissioner and increased the influence of other language entrepreneurs on educational language policy. The move towards decentralization, then, allowed the Partido Unión and the AMPR to increase their influence on Huyke's decisions.

\section{The Padín Language Policy, 1934-1949}

José Padín replaced the Miller/Huyke educational language policy with a new policy that reduced the role of English. Padín's approach began in 1934 and lasted until 1949, with an interruption during Commissioner José Gallardo's tenure, between 1937 and 1942 [18]. The new policy came into effect within the institutional rubric of the Jones Act. Contrary to the Falkner and Miller/Huyke periods, there were no fundamental regime rearrangements during Padín's tenure. However, demands for increased self-government did not diminish and by the 1930's the colonial relations faced one of their worst crises with the civil and official violence provoked by clashes between the colonial administration and separatist groups. Four large issues dominated the political arena of the time. First, there was an intensification of nationalist sentiments, ranging from artistic and literary expressions to the militant Partido Nacionalista. Second, the Partido Unión's undisputed control over domestic politics came to an end, which reduced the AMPR's influence on educational policies through legislation. Third, the AMPR recovered its influential institutional position on educational policies, which had eroded because of the break with Commissioner Huyke in 1926. Fourth, the rise in nationalist sentiments occurred within a climate of domestic demands for greater self-government, particularly for an elected governor. All these political dynamics took place within the context of a Puerto Rican economy that capsized into a dire depression, produced by a combination of crashing world stock markets, sinking global commodity demand and prices, and the effects of two ravaging hurricanes in the late 1920's.

The growth of Puerto Rican nationalism began during the last years of Falkner's policy, played an important role in the emergence of Miller's changes, and reemerged as a major force in influencing Padín's language policy reforms. The 1920's saw the creation of the Partido Nacionalista, a splinter from the Partido Unión, which emerged as a pro-independence movement with a strong anti-U.S. rhetoric and that by the mid 1930's advocated a strategy of armed struggle. The party never commanded the following of a majority, but was able to push the issue of defining Puerto Rico's political status into the agenda of colonial relations. Against this context, Americanizing practices 
became increasingly difficult to justify (Morris, 1990:35; Negrón de Montilla, 1990:195).

The intensification of nationalist sentiments coincided with the growth of opposition parties, particularly the Partido Socialista. The changing balance of electoral power prompted several electoral agreements between otherwise opposing parties, culminating in 1924 with the creation of the Alianza and the Coalición. The former resulted from the merge of the Partido Unión with a faction of the Partido Republicano, while the latter combined the Partido Socialista with the other faction of the Partido Republicano. The old alliance between the AMPR and the Unionistas became complicated by the inclusion of Republicano leaders. The types of educational legislative actions taken during the dominance of the Partido Unión were not reproduced with the Alianza. The AMPR's use of the legislative forum as an area of influence was reduced even further with the Coalición's victory in 1932.

Nevertheless, the reduction of the AMPR's legislative influence did not preclude its involvement in educational policies. After Padín's appointment in 1930, teachers and supervisors were asked to participate in formal and informal surveys about strategies to reform the instructional approach. The level of involvement in policy formulation by teachers and the AMPR provided by Padín had no precedent in all previous educational administrations. Thus, the growth in opposition political parties and Padín's relative opening of decision-making practices provoked a switch of the AMPR's arena of involvement, from the legislative front to the central office of the Education Department.

In the larger political context, the debate on political reform concentrated around the issue of United States citizenship. After the Jones Act, the public debate was focused on the demand for an elected Governor (Morales Carrión, 1983; Pagán, 1972; Vivas Maldonado, 1978). Padín's decentralizing reforms were seen as a symbol of greater self-government and welcomed by domestic politicians.

The climate surrounding the naming of Padín resembled that of Miller's appointment in 1915. Like Miller, Padín replaced a conflictive Commissioner who, regardless of his policies' merits, had not managed to establish either a favorable public opinion or an effective power base within the educational system. Also like Miller, Padín had risen through the Department's ranks and was perceived by most as an insider who knew the school system. Both men sparked favorable 
reactions after their appointments, and both raised expectations about potential educational reforms.

In 1934, José Padín announced a new educational language policy that made Spanish the language of instruction for all grades until eighth grade. The new policy was justified theoretically on grounds that children learned best in their mother tongue. Public reactions to Padín's policy varied. Padín's supporters-including the AMPR, the newly created Students Federation and the Unionistas in the Alianzaapplauded it and called him "the first true Puerto Rican Commissioner of Education" (Cebollero, 1945; Algren de Gutiérrez, 1987). Among his foes were the Republicanos in both the Alianza and the Coalición, and the Socialistas. The Nacionalistas also criticized Padín, for whom the inclusion of English courses contributed to American imperialism (Algren de Gutiérrez, 1987:96).

In 1937, Padín was succeeded by José M. Gallardo, who received a letter from United States President Franklin D. Roosevelt stressing the need to intensify the teaching of English in order to develop a bilingual population in the island (Cebollero, 1945:27; Osuna, 1949; López Yustos, 1997:162). As a result, Gallardo began in 1937 a series of pedagogical experiments that lasted until 1942, when he returned to Padín's approach. Gallardo's changes never amounted to a coherent educational language policy, and appeared to be geared more to appease Washington's concerns than to a conviction in a specific plan (Osuna, 1949). Padín's policy lasted until 1949, when Education Commissioner Mariano Villaronga established the educational language policy of using Spanish as the instructional medium for all school years, with English as a special subject.

\section{Language entrepreneurs: 1934-1949}

The major themes developed in this section refer to an institutionalization of teacher participation in the Education Department's central office, a restructuring of the educational system, and a shift in the AMPR's focus from the legislative arena to the internal structures of the Education Department.

\section{Teachers}

The evolution of teachers' working conditions from Falkner's (1904) to Padín's (1930) times was slow and had mixed results. The areas of policy involvement and job security experienced slow but steady improvements. Wages recuperated from the economic crisis of World 
War One, declined during the Great Depression of the 1930's, and recovered after 1936.

\section{Job security, wages, and classroom autonomy}

In the 1930's, Puerto Rican teachers saw an improvement in their job security, a decrease in salaries, and some increase of classroom autonomy. The first was due to the approval of The Teacher Selection Bylaws of 1932, which established ten specific criteria for the nomination of teachers and added the right to appeal decisions (circular letter 83, 1932). The second was produced by the contraction in the island's economy, while the third was produced by a betterment of the supervisors' training. Thus, with all its limitations, the new system improved the teachers' job security by establishing objective hiring criteria based on merit and seniority.

Teachers' wages experienced declines in the 1930's, as part of a total reduction in the Department's budget. Low teaching salaries fueled the exodus of teachers to other, better remunerated professions. A gradual recovery from the economic depression increased the Education Department's budget for teachers' salaries after 1936.

The attempt to change the supervisory emphasis from inspection to support provided a small increase in teachers' autonomy.

Superintendents received specialized training intended to improve their relations with teachers. The nature of the supervisory post never shifted from inspection to support, but the reform increased the superintendents' receptiveness to teachers' demands and increased the teachers' maneuvering room within their classrooms. Thus, while the increase in autonomy was small, it added an incentive towards an already growing teacher involvement.

\section{The Asociación de Maestros de Puerto Rico (AMPR)}

The AMPR's presence on educational decision-making was affected by the political realignment that created the Alianza in 1924. The inclusion of Republicanos in the Alianza effectively terminated the partnership between the Partido Unión and the AMPR, which in turn terminated the AMPR's influence on educational policies through legislation. However, the AMPR's decline in legislative influence was offset by an increased involvement in decision-making within the Education Department. With Padín's appointment, the association gained new ground by being included in a series of surveys and consultations that led to the new policy of 1934. 
The AMPR's posture towards the language question had remained constant since its creation in 1912, and Padín's policy fell short of that goal. However, it represented a step closer than the Miller/Huyke policy and was welcomed by the AMPR. The fact that an Education Commissioner like Padín-committed to an all-Spanish instruction since at least 1915 and validated by the AMPR-, did not place Spanish as the instructional medium for all grades, testifies to the strong pressures stemming from the central government administration towards a language rationalization based on English.

\section{Administrators}

On July of 1931 José Padín restructured the Department of Education by dividing the Department between technical and administrative areas, and by placing an Assistant Commissioner at the head of each division (Osuna, 1949:271). The general effect of the reform was a relative decentralization of the Department's operations, by delegating several tasks that were previously concentrated on the Commissioner's office.

\section{Central Office}

The office of the Commissioner of Education experienced no fundamental changes from the Jones Act to Padín's tenure. However, the 1931 reforms provided for a fundamental change in educational policy-making. The division between technical and administrative areas within the Education Department injected a higher dose of professionalism to the department's operations, since it promoted specialization in services and reduced the inherence of administrators over strictly instructional decisions. The Commissioner retained large powers within the Department but, relative to the previous thirty years, Padín's reform moved the decision-making process a notch away from the otherwise quasi-absolute centralization.

Besides the 1931 reforms, Padín established a more open system of decision-making, which included consultation of teachers (individuals and organized) and PTA's. The more participatory structure was influenced by Padín's own style and by the experience of his predecessor's last years in the post, in which the break with the AMPR obstructed the Commissioner's capacity to run the school system's operations efficiently and showed the need to maintain a working relation with the teachers' guild.

Commissioner Padín also faced strong pressures from the colonial administration and from Washington to maintain language rationalization practices. Governors Theodore Roosevelt Jr., Robert 
Gore, and Blanton Winship, expressed dissatisfaction with Padín's emphasis on Spanish. The pressures for language rationalization did not vanish the effects of teachers' influence and decentralizing institutional changes, but limited Padín's drive towards an all-Spanish instruction.

The relative increases in openness and decentralization had two important effects on policy-making procedures. First, they allowed for an expansion in policy influence by non-administrative sectors, particularly the teachers, through the AMPR. Second, the specialization of duties between administrative and technical areas split the decision-making process and separated instructional from administrative matters, which in turn reduced the influence of purely administrative perspectives from educational decisions.

\section{Supervisors}

The 1931 reform attempted to refurbish the supervisory posts by exposing supervisors to current theories. Its intention was to professionalize the post and to reduce the resentments between superintendents and teachers, provoked by the latter's perception of the former as hostile inspectors, loyal to the Education Commissioner and unresponsive to lower-levels of the hierarchy. The reforms included courses for superintendents (the term used for supervisors during Padíns tenure) in the supervision of instruction at the University of Puerto Rico (Osuna, 1949:276). The reality, however, was that superintendents and their representatives (assistant superintendents), faced strong pressures to respond to central office commands. Education Commissioner's circular letters continued to delineate specific instructions to superintendents, to be passed along and enforced at lower levels. Thus, while the supervisory post was improved through college courses and stricter requirements, the nature of the post changed only slightly and supervisors' capacity for independent involvement in policy-making remained low.

\section{Municipal Commissioners}

The 1925 Act Reorganizing the Municipal Government created the post of Municipal Commissioner, who substituted the school boards for a mayor-appointed officer (Osuna, 1949:309). The post was renamed as school director with the reforms, but the nature of the officer's duties remained intact. School directors were still appointed by the town mayors with the consent of the municipal assemblies. They represented the links between the central office and the municipal school regions, and their roles concentrated on enforcing directives from the central office, while presenting feedback and 
advice to the Commissioner about local conditions. Like the supervisors, Municipal Commissioners had minor roles in decisionmaking, so their preferences had little impact in Padín's educational policy.

\section{Parents}

The period before the establishment of Padín's policy did not experience the kind of parent (and student) activism seen before Miller's. However, the Insular League of Parent-Teachers Associations established a presence in the Puerto Rican school system, and in 1926 served as mediator in the Huyke-AMPR impasse (Morris, 1995:36; Negrón de Montilla, 1990:238). Also, PTA's emerged rapidly throughout the island: by the time of Padín's appointment the number of parent-teacher associations surpassed 1,100, and by 1935 there were over 1,200 (circular letter 55, 1935). However, almost half of the individual PTA's were not affiliated with the Insular League, which limited the latter's legitimacy over claims of representing Puerto Rico's parents (Osuna, 1949). Hence, the Insular League of PTA's was supported by the central office and participated in policy-making in advisory capacities, but its low membership limited its claim to universal representation.

\section{Political parties and politicians}

The period under consideration here experienced a shift in the balance of power of domestic political parties, in which strategic considerations produced a series of electoral alliances among otherwise adversarial political forces.

Those alliances reduced the impact of legislation and direct political pressures on educational language policies. The Partido Unión, a traditional language entrepreneur against Americanizing practices in the school system, lost its dominance in domestic politics. The Alianza included Republicano leaders and broke the party's consensus on the language question. The effect on legislation was immediate, since no bills making Spanish the medium of instruction in public schools were passed during the Alianza and Coalición periods, a stark contrast with the Partido Unión's tenure, when several such bills were debated and approved. It was not until 1946 that another bill regarding the use of English in education was approved in Puerto Rico's legislature.

The disappearance of language legislation diminished the role of Unionistas as language entrepreneurs during the last years of Huyke's tenure and through Padín's administration. Consequently, the AMPR's influence on language legislation was suspended until the emergence 
of the Partido Popular in the 1940's. From this perspective, the AMPR's participation in educational policies suffered a setback that was only compensated by internal developments within the Department of Education.

\section{Institutional causes of Padín's Policy}

Padín's educational language policy was produced by the decentralizing effect of the 1931 school system reform and by an increase in policy involvement of the AMPR and the Parent-Teachers Associations. In addition to structural changes, Puerto Rico's political climate of increased nationalist sentiments provided strong expectations for a policy change geared towards a growth on the use of Spanish as instructional medium.

In 1934, Education Commissioner José Padín announced the new language policy. The societal use of English in Puerto Rico continued growing, due to Puerto Rico's escalating integration into the American economy and to the long-term effects of Americanizing educational policies. The effects were an expansion in the number of American business managers in the island, and a growth in contact with Englishspeakers by Puerto Rican entrepreneurs who depended on the American market for exports and imports. Educational language policies, on the other hand, had produced a generation of Puerto Rican children who had received most of their schooling in English and who, even with the many inefficacies of the use of English as instructional medium-indicated on various occasions by several academic studies [19]-had developed a familiarity with the English language unknown by their parents' generation.

The nationalist climate that preceded the new policy increased expectations for an educational policy change, while the 1931 reform created the context under which a new policy became possible. The reform generated a specialization of services and functions, and stressed the professional nature of supervision. Separating technical from administrative functions limited the involvement of administrators into educational policies, and reduced the centrality of the Education Commissioner. To be sure, the Commissioner retained the last word in most decisions, but the reform involved more individuals in the decision-making process and delegated responsibilities.

The AMPR's involvement in educational policy experienced a shift in focus and an intensification in influence. The dissolution of the Partido Union's quasi-hegemony in legislative affairs reduced the AMPR's influence on educational policy through legislation. After the creation of the Alianza and the Coalición, the language question was dropped 
from the legislative agenda. The AMPR lost its preeminent presence in the legislative front. However, increases in participatory channels for the teachers' guild improved their influence over educational policy within the ranks of the Education Department. Padín acknowledged the AMPR's position and invited the association into a series of consultations and surveys that influenced the new educational language policy established in 1934.

Parents' participation also grew during Padín's tenure. One reason was the proliferation of Parent-Teachers Associations throughout the island, greatly encouraged by the Education Department and Padín. The other reason was Padín's inclusiveness of non-bureaucratic sectors. The Insular League of PTA's was included in the process that led to the new educational language policy, even if its participation was limited to support and consultation and had no real decisionmaking power.

In conclusion, during the four years before Padín's policy change of 1934, the Department of Education experienced a structural reform that provided several decentralizing elements, while teachers and parents were able to influence policy-making through their participation in the consultation process between 1930 and 1934. The rise of Puerto Rican nationalism provided expectations for a policy change that would increase the emphasis on Spanish as instructional medium. Finally, language rationalization pressures from the central government, through the Governor of Puerto Rico, precluded Padín from establishing an even larger role for Spanish, in spite of his previous rhetoric that supported Spanish as the medium of instruction for all school years.

\section{Conclusion}

This paper set to establish the relation between politics and language as it is evidenced through the process of educational policies. It evaluated the political nature of language contact in five major areas. It also stated that the formation of educational policies involves power dynamics among three main sets of actors: administrators, teachers, and parents. The school system is an arena in which different, and sometimes contradictory, interests are reconciled. The process involves tensions that may impose obstacles towards the involvement of teachers and parents in educational policy that, in turn, may curb innovation. Educational institutions can help solve the challenge of static school systems derived from the rational actions of administrators, teachers, and parents, by changing the expected utilities of each group and allowing them to make rational decisions 
under different sets of payoffs, which may stimulate reform and adaptation of educational systems.

One policy area where innovation may be most helpful is that related to language. Decentralized and participatory educational institutions may provide incentives for the inclusion of communities' interests through the inclusion of non-bureaucratic groups at local levels. The inclusion of those interests may provide policy makers with tools that are important for the effective resolution of the challenges posed by pressures from language groups to include minority languages in educational curricula.

\section{Notes}

1 Connor, 1994; Smith, 1992; Kohn, 1982; Anderson, 1991.

2 This is an extension of Popkin's notion of a political entrepreneur, "someone willing to invest his own time and resources to coordinate the inputs of others in order to produce collective action or collective goods" (Popkin, 1979: 259).

3 There are somewhere between 180 and 200 states in the world, while there are over 4,000 languages. The ratio is over 20 languages per country on average. This ratio says little about the distribution of language diversity worldwide, but illustrates how most countries confront some level of language diversity.

4 Several studies of this nature have been conducted in Quebec since 1960. For comprehensive reviews of these studies and their implications for language legislation in Quebec and elsewhere, see Hamers and Hummel (1994), and Fasold (1987).

5 Language rationalization is the increase in government efficiency by the selection of the smallest number possible of languages for official and public use (Laponce, 1987).

6 In 1979 the Canadian Supreme Court declared unconstitutional a section of Quebec's Bill 101 (the Charter of the French Language of 1977) that declared that only the French version of Quebec's laws were official. Bill 101 was challenged again in 1984 and the Canadian Supreme Court ruled unconstitutional the limitations of eligibility to English-language schooling for Anglophones from provinces other than Quebec. The language provisions of Bill 101 remained in effect, however, due to the Anotwithstanding@ clause, which permitted Canadian autonomous regions to maintain unconstitutional practices for a limited period of time. For detailed discussions on this and other 
related subjects, see Bourhis (1994), Meadwell (1993), or Bonk (1990).

7 Colonial languages have also served as tools for national unification in countries with wide linguistic differences, particularly in the Indian subcontinent and Africa (Grosjean, 1982; Laitin, 1992).

8 Beadie (1996) illustrates this point with a school reform project in Illinois in 1992, which faced adamant and adverse reactions from teachers who believed that their influence decreased with the new plan, even if it formally appeared to have expanded their participation in policy-making.

9 The debate gravitated around the legal status of the newly acquired islands, particularly Cuba, the Philippines, and Puerto Rico. Since previous territorial acquisitions by the United States had evolved into their inclusion in the Union, the question became whether the incorporation of the new territories would pose a legal obligation to admit them into the Union. The fact that the islands were inhabited by non Anglo-Saxon populations sparked a controversy around the genetic capacities of Spanish-Caribbeans and Filipinos to govern themselves and develop productive economies (as opposed to what they believed were the genetic inclinations of Anglo-Saxons towards democratic and efficient economic institutions). Finally, the territories were declared unincorporated, which avoided a commitment towards admission into the Union (see Cabán, 1998; Barreto, 1995).

10 The Commissioner also held the following posts: Member of the Public Service Commission, President of the Board of Trustees of the University of Puerto Rico, President of the Board of the Carnegie Library, President of the Teachers' Pension Board, and Chairman of the Chapter School Committee of the Puerto Rico Chapter of the American National Red Cross (Osuna, 1949:141).

11 The use of English as instructional medium was probably the most controversial policy, but not the only one. The first clash with Puerto Rican teachers occurred with the implementation of the Americanstyle academic calendar, which disregarded Puerto Rican holidays. For instance, the new calendar excluded the holiday of January 6 , Three Kings' Day, which, under Puerto Rican cultural tradition, was (and still is) among the most sacred days of Christmas and one of the most important holidays of the year. 
12 During the academic year of 1904-1905, the island only had three high schools (altas escuelas) and a total of 1,024 schools (Dexter, 1908).

13 The Partido Unión's platform included support for federal statehood, autonomy, and independence, which may appear contradictory from a contemporary perspective. However, the main emphasis was not on sovereignty but on self-government, which either formula appeared to offer. Claims for self-government dated to the last stage of Spanish rule, when the Autonomy Charter was gained by Puerto Rican politicians, only a year before the U.S. invasion and the subsequent political reversal by the U.S. military government.

14 The curriculum organization was a straight application of Massachusetts' school curriculum, and the texts offered little sensibility towards Puerto Rican cultural idiosyncracies. This fact was recognized by Falkner, who noted as a symbolic example how a school text illustrated a mathematical problem with peaches, which were unknown to most Puerto Rican children at the time, when it would have made more sense to illustrate it with a familiar fruit, like bananas (Negrón de Montilla, 1990:110).

15 The AMPR, from its inception until 1946, approved an annual resolution rejecting the use of English as instructional medium.

16 While there was not one set of American cultural norms, they were interpreted as those of the mainstream, Anglo-Saxon majority in the United States. However, students who received scholarships by the Education Department to U.S. universities were mostly sent to traditionally African-American colleges, such as Howard University, where they experienced a different side of U.S. culture and lifestyle.

17 In the school year 1913-1914, for instance, of all students enrolled in secondary schools, only $7.6 \%$ enrolled in 9th grade eventually graduated from 12th grade (Bainter, 1914:361).

18 The changes made by Gallardo are not considered here part of a different policy because they did not become a clear policy and because they were reversed in 1942.

19 Studies include Padín, 1916; Teachers' College International Institute, 1926; and Gray, 1936. Clark's study (1930), was among the strongest defenders of English as instructional medium.

\section{References}


Algren de Gutiérrez, Edith. The Movement Against Teaching English in Schools of Puerto Rico. Lanham, MD: University Press of America, 1987.

Anderson, Benedict. Imagined Communities: Reflections on the Origin and Spread of Nationalism (1983). London: Verso, 1991.

---. Language and Power: Exploring Political Cultures in Indonesia. Ithaca: Cornell University Press, 1990.

Arrigoitia, Delma S. José de Diego, El Legislador: Su Visión de Puerto Rico en la Historia (1903-1918). San Juan, Puerto Rico: Instituto de Cultura Puertorriqueña, 1991.

Babault, Sophie, and Caitucoli, Claude. "Linguistic Policy and Education in Francophone Countries." In Wodak and Corson 1997: 159-167.

Bacharach, Samuel B., Mundell, Bryan L. "Organizational Politics in Schools: Micro, Macro, and Logics of Action." Educational Administration Quarterly 29 (4), 1993: 423-452.

Barreto, Amílcar Antonio. "Nationalism, Linguistic Security, and Language Legislation in Quebec and Puerto Rico." Diss. State University of NY: Buffalo 1995.

---. Language, Elites, and the State: Nationalism in Puerto Rico and Quebec. Westport, Ct: Praeger, 1998.

Barrows, David P. "Education and Social Progress in the Philippines." The Annals of the American Academy of Political and Social Science 30, 1907: 69-82.

Bates, Robert H. "Contra Contractarianism: Some Reflections on the New Institutionalism." Politics and Society 16, 1988: 387-401.

Bates, Robert H. "Social Dilemmas and Rational Individuals: An Essay on the New Institutionalism." Unpublished manuscript, Duke University, 1992.

Bauch, Patricia A. and Goldring, Ellen B. "Parent-Teacher Participation in the Context of School Governance." Peabody Journal of Education 73 (1), 1998: 15-35. 
Bayron Toro, Fernando. Elecciones y Partidos Políticos de Puerto Rico. Mayagüez, Puerto Rico: Editorial Isla, 1984.

Beadie, Nancy. "From Teacher as Decision Maker to Teacher as Participant in Shared Decision Making: Reframing the Purpose of Social Foundations in Teacher Education." Teachers College Record 98 (1), 1996: 77-103.

Becker, Henry J., Nakagawa, Kathryn, and Corwin, Ronald G. "Parent Involvement Contracts in California's Charter Schools: Strategy for Educational Improvement or Method of Exclusion?" Teachers College Record 98 (3), 1997: 511-536.

Blase, Joseph (ed). The Politics of Life in Schools: Power, Conflict, and Cooperation. London: Sage, 1991.

Bonk, Paul. "Incentive Structures, Cultural Communities and Ethnonationalism." Diss. Rutgers University, New Brunswick, 1990.

Bourhis, Richard Y. "Introduction and Overview of Language Events in Canada." International Journal of the Sociology of Language 105/106, 1994: 5-36.

Boyan, Norman J. (ed.). Handbook of Research on Educational Administration. New York: Longman, 1988.

---. "Describing and Explaining Administrator Behavior." Handbook of Research on Educational Administration, 1988: 77-98.

Bright, William. Sociolinguistics. The Hague: Mouton, 1966.

Brumbaugh, Martin G. "An Educational Policy for Spanish-American Civilization." The Annals of the American Academy of Political and Social Science 30, 1907: 65-68.

Bryant, Nita. "Reducing the Relational Distance Between Actors: A Case Study in School Reform." Urban Education 33(1), 1998: 34-49.

Cabán, Pedro. "Americanization, Sovereignty and Citizenship: The United States and Puerto Rico, 1898?1917." Unpublished manuscript, Rutgers University, 1998.

Casanova, Ursula. "Parent Involvement: A Call for Prudence." Educational Researcher 25 (8), 1996: 30-32. 
Cebollero, Pedro A. A School Language Policy for Puerto Rico. San Juan, P.R: Imprenta Baldrich, 1945.

Cioffi-Revilla, Claudio, Merritt, Richard, and Zinnes, Dina A. (eds.). Communication and Interaction in Global Politics. London: Sage, 1987.

Clampitt-Dunlap, Sharon. "Nationalism and Native-language Maintenance in Puerto Rico." International Journal of the Sociology of Language 142, 2000: 25-34.

Clark, Victor S. Porto Rico and Its Problems. Washington, DC: The Brookings Institution, 1930.

Clune, William H. "The Best Path to Systemic Educational Policy: Standard/Centralized or Differentiated/Decentralized?" Educational Evaluation and Policy Analysis 15 (3), 1993: 233-254.

Conley, Sharon. "Review of Research on Teacher Participation in School Decision Making." Review of Research in Education 17, 1991: 225-266.

Connor, Walker. Ethnonationalism: The Quest for Understanding. Princeton, New Jersey: Princeton University Press, 1994.

--- "Nation Building or Nation Destroying?" World Politics 24 (3) 1972: 319-355.

Corwin, Ronald G. and Borman, Kathryn M. "School as Workplace: Structural Constraints on Administration." Handbook of Research on Educational Administration. New York: Longman, 1988. 209-238.

Crawford, James. Bilingual Education: History, Politics, Theory and Practice. Trenton: Crane Publishing Company, 1989.

---. Language Loyalties: A Source Book on the Official English Controversy (Ed.). Chicago: The University of Chicago Press, 1992.

Crystal, David. The Cambridge Encyclopedia of Language. Cambridge: Cambridge University Press, 1997.

DasGupta, Jyotirindra. Language Conflict and National Development: Group Politics and National Language Policy. Berkeley: University of California Press, 1970. 
---. "Multicultural Federalism and National Development: India's Institutional Learning." Unpublished manuscript presented at the APSA Annual Meeting, Boston, MA, 1998

Deutsch, Karl W. "Social Mobilization and Political Development." American Political Science Review 55 (3), 1961: 493-514.

---. Nationalism and Social Communication: An Inquiry Into the Foundations of Nationality. Cambridge, MA: MIT Press, 1966.

Dion, Douglas. "Evidence and Inference in the Comparative Case Study." Comparative Politics 30 (1), 1998: 127-145.

Dodd, Anne Wescott. "Involving Parents, Avoiding Gridlock." Educational Leadership 53 (6), 1996: 44-47.

Duke, Daniel L., Showers, Beverly K., and Imber, Michael. "Teachers and Shared Decision Making: The Costs and Benefits of Involvement." Educational Administration Quarterly 16 (1), 1980: 93-106.

Dutcher, Nadine. The Use of First and Second Languages in Primary Education: Selected Case Studies. World Bank Staff Working Papers No. 504. Washington, DC: The World Bank, 1982.

Eastman, Carol M. "Dissociation: a Unified Language-Policy for Kenya." International Journal of the Sociology of Language 86, 1990: 69-85.

Epstein, Joyce L. "A Response." Teachers College Record 94 (4), 1993: $710-712$.

Esman, Milton J. Ethnic Politics. Ithaca: Cornell University Press, 1994.

Esteva i Fabregat, Claudi. "Ethnocentricity and Bilingualism in Catalonia: the State and Bilingualism." International Journal of the Sociology of Language 47, 1984: 43-57.

Fasold, Ralph. The Sociolinguistics of Society. Oxford: B. Blackwell, 1987.

Ferguson, Charles A. "Diglossia." Word 15, 1959: 325-340.

---. "National Sociolinguistic Profile Formulas." Sociolinguistics. The Hague: Mouton, 1966. 309-324. 
Fine, Michele. "Apparent Involvement: Reflections on Parents, Power, and Urban Public Schools." Teachers College Record 94, 1993: 682710.

Fishman, Joshua A. "Language Maintenance and Language Shift as Fields of Inquiry." Linguistics 9, 1964: 32-70.

---. "Bilingualism with and without Diglossia; Diglossia with and without Bilingualism." Journal of Social Issues 32, 1967: 29-38.

---. Readings in the Sociology of Language (ed.). The Hague: Mouton, 1968.

---. Advances in the Study of Societal Multilingualism (ed.). The Hague: Mouton, 1978.

Fishman, Joshua A., Ferguson, Charles and Das Gupta, Jyotirindra (eds.). Language Problems of Developing Nations. New York: John Wiley and Sons, 1968.

Fortier, D'Iberville. "Official Languages in Canada: a Quiet Revolution." International Journal of the Sociology of Language 105/106, 1994: 69-97.

Fuhrman, S. H., and Malen, B. (eds.). The Politics of Curriculum and Testing. London: Taylor and Francis, 1990.

Futrell, Mary Hatwood. "Teachers in Reform: The Opportunity for Schools." Educational Administration Quarterly 24 (4), 1988: 374-380.

García Martínez, Alfonso L. Puerto Rico: Leyes Fundamentales. Río Piedras, P.R: Edil, 1982.

Geertz, Clifford. The Interpretation of Cultures: Selected Essays. New York: Basic Books, 1973.

Gellner, Ernest. Nations and Nationalism. Ithaca, NY: Cornell University Press, 1983.

Greenberg, Joseph H. "The Measurement of Linguistic Diversity." Language 32 (1), 1956: 109-115.

Greenfield, William D., Jr. "Toward a Theory of School Administration: The Centrality of Leadership." Educational Administration Quarterly 31 (1), 1995: 61-85. 
Gray, S. Williams. "Carta al Comisionado de Instrucción de Puerto Rico," The Porto Rico School Review 20 (8), 1936: 5-32.

Grosjean, François. Life With Two Languages: An Introduction to Bilingualism. Cambridge, MA: Harvard University Press, 1982.

Gumperz, John J. "Linguistic and Social Interaction in Two Communities." American Anthropologist 66, 1964: 137-53.

Hamers, Josiane F. and Hummel, Kirsten M. "The Francophones in Quebec: Language Policies and Language Use." International Journal of the Sociology of Language 105/106, 1994: 127-152.

Hannaway, Jane, and Carnoy, Martin (eds.). Decentralization and School Improvement: Can We Fulfill the Promise? San Francisco: Jossey-Bass, 1993.

Hannaway, Jane, and Lockheed, Marlaine E. (eds.). The Contributions of the Social Sciences to Educational Policy and Practice: 1965-1985. Berkeley: McCutchan, 1986.

Hill, Paul T. "A Public Education System for the New Metropolis." Education and Urban Society 29 (4), 1997: 490-508.

Hobsbawm, Eric and Ranger, Terence (eds.). The Invention of Tradition. Cambridge: Cambridge University Press, 1983.

Hobsbawm, Eric. The Age of Revolution, 1789-1848. New York: Mentor, 1964.

International Institute of Teachers College, Columbia University. $\underline{A}$ Survey of the Educational System of Porto Rico. New York: Columbia University, 1926.

Keith, Novella Z. "A Critical Perspective on Teacher Participation in Urban Schools." Educational Administration Quarterly 32(1), 1996: 4579.

Kerchner, C. T., and Koppich, J. E. A Union of Professionals: Labor Relations and Educational Reform. New York: Teachers College, 1993.

King, Gary, Keohane, Robert O., and Verba, Sidney. Designing Social Inquiry: Scientific Inference in Quantitative Research. Princeton: Princeton University Press, 1994. 
Kloss, Heinz. "Notes Concerning a Language-Nation Typology." In Language Problems of Developing Nations. Fishman, Joshua A., Ferguson, Charles and Das Gupta, Jyotirindra (eds.). New York: John Wiley and Sons, 1968. 69-86.

Kohli, Atul, et al. "The Role of Theory in Comparative Politics; A Symposium." World Politics 48, 1995: 1-49.

Kohn, Alfie. "Only for My Kid: How Privileged Parents Undermine School Reform." Phi Delta Kappan 79 (8), 1998: 568-577.

Kohn, Hans. Nationalism: Its Meaning and History. Malabar, Fla: Robert E. Krieger Publishing Co., 1982.

Kuo, Eddie C. Y. "Measuring Communicativity in Multilingual Societies: The Case of Singapore and Malaysia." Anthropological Linguistics 21(7), 1979: 328-40.

López Laguerre, María M. El Bilingüismo en Puerto Rico: Actitudes Socio-Lingüísticas del Maestro. San Juan, Puerto Rico: Editorial Espuela, 1997.

Laitin, David. Politics, Language, and Thought: The Somali Experience. Chicago: University of Chicago Press, 1977.

---. "Language Games." Comparative Politics 20, 1988: 289-302.

---. Language Repertoires and State Construction in Africa. Cambridge: Cambridge University Press, 1992.

---. "What is a Language Community?" Unpublished paper presented at the APSA Annual Meeting, Boston, MA, 1998.

Laitin, David, Solé, Carlota, and Kalyvas, Stathis N. "Language and the Construction of States: The Case of Catalonia in Spain." Politics and Society 22 (1), 1994: 5-29.

Laponce, J.A. 1987. "Language and Communication: The Rise of the Monolingual State." In Communication and Interaction in Global Politics. Cioffi-Revilla, Merritt, and Zinnes (eds.). London: Sage, 1987. 183-208.

Lauglo, Jon. "Forms of Decentralization and their Implications for Education." Comparative Education 31 (1) 1995: 5-29. 
Lewis, Anne C. "Changing Views of Parental Involvement." Phi Delta Kappan 76, 1995: 430-431.

Lieberson, Stanley. "An Extension of Greenberg's Linguistic Diversity Measures." Language 40 (4), 1964: 526-531.

Lockheed, Marlaine E., Verspoor, Adriaan, and associates. Improving Primary Education in Developing Countries. Oxford: Oxford University Press, 1991.

López Laguerre, María M. El Bilingüismo en Puerto Rico: Actitudes Socio-lingüísticas del Maestro. San Juan, P.R: Editorial Espuela, 1997.

López Yustos, Alfonso. Historia Documental de la Educación en Puerto Rico, 1503-1970. Hato Rey, Puerto Rico: Publicaciones Puertorriqueñas, Inc., 1997.

Mackey, William F. "Mother Tongues, Other Tongues and Link Languages: What They Mean in a Changing World." Prospects 22, 1992: 1.

Marshall, Catherine. "The Chasm Between Administrator and Teacher Cultures: A Micropolitical Puzzle." In The Politics of Life in Schools: Power, Conflict, and Cooperation. Blase, Joseph (ed). London: Sage, 1991. 139-160.

Mazrui, Alamin M. "Language Policy and the Foundations of Democracy: An African Perspective." International Journal of the Sociology of Language 118, 1996: 107-124.

Meadwell, Hudson. "The Politics of Nationalism in Quebec." World Politics 45, 1993: 203-41.

Mkilifi, M. H. Abdulaziz. "Triglossia and Swahili-English Bilingualism in Tanzania." In Advances in the Study of Societal Multilingualism. Fishman, Joshua (ed.). The Hague: Mouton, 1978. 129-152.

Mohrman, A. M., Cooke, R. A., and Mohrman, S. A. "Participation in Decision Making: A Multidimensional Perspective." Educational Administration Quarterly 14 (1), 1978: 12-29.

Morales Carrión, Arturo. Puerto Rico: A Political and Cultural History. New York: W. W. Norton \& Company, 1983. 
Morris, Nancy. Puerto Rico: Culture, Politics, and Identity. Westport, Conn: Praeger, 1995.

Negrón de Montilla, Aida. La Americanización de Puerto Rico y el Sistema de Instrucción Pública, 1900-1930. Río Piedras: Editorial de la Universidad de Puerto Rico, 1990.

Olson, Mancur. The Logic of Collective Action: Public Goods and the Theory of Groups. Cambridge: Harvard University Press, 1971.

Osuna, Juan José. A History of Education in Puerto Rico. Río Piedras, P.R: University of Puerto Rico Press, 1949.

Padín, José. The Problem of Teaching English to the People of Puerto Rico. San Juan, P.R: Department of Education, 1916.

Pagán, Bolívar. Historia de los Partidos Políticos Puertorriqueños. 2 vols. San Juan, Puerto Rico: Librería Campos, 1972.

Parasher, S.V. "Mother Tongue-English Diglossia: A Case Study of Educated Indian Bilinguals' Language Use." Anthropological Linguistics 22(4), 1980: 151-162.

Platt, John T. "A Model for Polyglossia and Multilingualism (with Special Reference to Singapore and Malaysia)." Language in Society 6, 1977: 361-378.

Popkin, Samuel L. The Rational Peasant: The Political Economy of Rural Society in Vietnam. Berkeley: University California Press, 1979.

Puerto Rico Department of Education. Circular Letters. Unpublished. San Juan, Puerto Rico, 1903-1998.

---. Annual Report of the Commissioner of Education. Washington, D.C: Government Press, 1899-1944.

---. Proyecto Para Formar Un Ciudadano Bilingüe. Unpublished manuscript, 1997.

Quintero Rivera, Angel. Conflictos de Clase y Política en Puerto Rico. Río Piedras, Puerto Rico: Huracán, 1984.

Rahman, Tariq. "The Punjabi Movement in Pakistan." International Journal of the Sociology of Language 122, 1996: 73-88. 
Rigual, Néstor. Reseña de los Gobernadores de Puerto Rico: 19001930. Río Piedras, P.R: Editorial Universitaria, 1967.

Rodino, Ana María. "Language Rights and Education for the AfroCaribbean English-Speaking Minorities in Central America:

Contributions to the Discussion on Bilingual Education in Costa Rica." La Educación 20, 1992: 137-154.

Rodríguez Bou, Ismael. Estudio del Sistema Educativo de Puerto Rico, Vols. 1\&2. Río Piedras, P.R: University of Puerto Rico Press, 1960.

Sabater, Ernest. "An Approach to the Situation of the Catalan Language: Social and Educational Use." International Journal of the Sociology of Language 47, 1984: 29-41.

School Laws of Puerto Rico. 1914.

Schweers, C. William, Jr., and Hudders, Madeleine. "The Reformation and Democratization of English Education in Puerto Rico." International Journal of the Sociology of Language 142, 2000: 63-87.

Shedd, Joseph B. "Collective Bargaining, School Reform, and the Management of School Systems." Educational Administration Quarterly 24 (4), 1988: 405-415.

Smith, Anthony. The Ethnic Origins of Nations. Oxford: Blackwell, 1986.

---. Ethnicity and Nationalism (ed.). New York: E. J. Brill, 1992.

Smith, M.S, and O'Day, J. 1990. "Systemic School Reform." In The Politics of Curriculum and Testing. Fuhrman, S. H., and Malen, B. (eds.). London: Taylor and Francis, 1990. 233-267.

Solé, Yolanda. 1995. "Language, Nationalism, and Ethnicity in the Americas." International Journal of the Sociology of Language 116, 1995: 111-137.

Solís, José. Public School Reform in Puerto Rico: Sustaining Colonial Models of Development. Westport, CT: Greenwood, 1994.

Stewart, William. "A Sociolinguistic Typology for Describing National Multilingualism." In Fishman, Joshua (ed.). Readings in the Sociology of Language. The Hague: Mouton, 1968. 531-45. 
Teachers' College International Institute, Columbia University. $\underline{A}$ Survey of the Public Education System of Puerto Rico. New York: Teachers' College Bureau of Publications, 1926.

Tyack, David. 1993. "School Governance in the U.S: Historical Puzzles and Anomalies." In Decentralization and School Improvement: Can We Fulfill the Promise? Hannaway, Jane, and Carnoy, Martin (eds.). San Francisco: Jossey-Bass, 1993. 1-32.

Valleverdú, Francesc. "A Sociolinguistic History of Catalan." International Journal of the Sociology of Language 47, 1984: 13-28.

Vélez, Jorge A. "Understanding Spanish-Language Maintenance in Puerto Rico: Political Will Meets the Demographic Imperative." International Journal of the Sociology of Language 142, 2000: 5-24.

Verdugo, Richard R., Greenberg, Nancy M., Henderson, Ronald D., Uribe, Oscar Jr., and Schneider, Jeffrey M. "School Governance Regimes and Teachers' Job Satisfaction: Bureaucracy, Legitimacy, and Community." Educational Administration Quarterly 33(1), 1997: 38-66.

Vexliard, Alexandre. "Centralization and Freedom in Education." Comparative Education 6 (1), 1970: 37-47.

Vincent, Carol. "Parent Empowerment? Collective Action and Inaction in Education." Oxford Review of Education 22 (4), 1996: 465-482.

Vivas Maldonado, José Luis. Historia de Puerto Rico. New York: L.A. Publishing, 1978.

Weinstein, Brian (ed.). Language Policy and Political Development. Norwood, NJ: Ablex Publishing Corp, 1990.

Weiss, Carol H. "Shared Decision Making About What? A Comparison of Schools with and without Teacher Participation." Teachers College Record 95 (1), 1993: 69-92.

Wissler, Dorothy F. and Ortiz, Flora Ida. "The Decentralization Process of Schools Systems: A Review of the Literature." Urban Education 21 (3), 1986: 280-294.

Wodak, R. and Corson, D. (eds.). Encyclopedia of Language and Education, Vol. I: Language Policy and Political Issues in Education. Amsterdam: Kluwer Academic Publishers. 
World Bank. Priorities and Strategies for Education: A World Bank Review. Washington, D. C: The World Bank, 1995. 